\title{
MANAGEMENT OF ENDOCRINE DISEASE Risk of overtreatment in patients with adrenal insufficiency: current and emerging aspects
}

\author{
G Mazziotti ${ }^{1}$, A M Formenti ${ }^{2}$, S Frara ${ }^{3}$, E Roca ${ }^{4}$, P Mortini $^{5}$, A Berruti ${ }^{4}$ and \\ A Giustina ${ }^{3}$
}

${ }^{1}$ Endocrinology Unit, ASST, Carlo Poma, Mantua, Italy, 2Department of Molecular and Translational Medicine, University of Brescia, Brescia, Italy, ${ }^{3}$ Chair of Endocrinology, San Raffaele Vita-Salute University, Milan, Italy, ${ }^{4}$ Chair of Medical Oncology, University of Brescia, Brescia, Italy, and ${ }^{5}$ Chair of Neurosurgery, San Raffaele Vita-Salute University, Milan, Italy

Correspondence should be addressed to A Giustina

Email

a.giustina@libero.it

Abstract

The effects of long-term replacement therapy of adrenal insufficiency (AI) are still a matter of controversy. In fact, the established glucocorticoid replacement regimens do not completely reproduce the endogenous hormonal production and the monitoring of Al treatment may be a challenge for the lack of reliable clinical and biochemical markers. Consequently, several Al patients are frequently exposed to relative glucocorticoid excess potentially leading to develop chronic complications, such as diabetes mellitus, dyslipidemia, hypertension and fragility fractures with consequent impaired QoL and increased mortality risk. This review deals with the pathophysiological and clinical aspects concerning the over-replacement therapy of primary and secondary Al.

\section{Introduction}

Adrenal insufficiency (AI) is a severe and potentially lifethreatening disease caused by a primary or secondary impairment of function of adrenocortical cells. Thomas Addison firstly described the clinical picture of the disease characterized by lassitude, fatigue, weight loss and skin hyperpigmentantion associated with a 'remarkable form of anemia' attributed to a pathological condition of 'suprarenal capsules' (1). Before the availability of synthetic glucocorticoids, all patients with AI died within 5 years of diagnosis (2). The outcome of disease greatly improved after availability of hydrocortisone (3), but the effects of long-term replacement therapy of AI are still a matter of controversy. In fact, one could argue that the longterm replacement therapy with glucocorticoids should have no negative effects due to its substitutive nature (4). However, over the last years, it has become evident (c) 2017 European Society of Endocrinology Printed in Great Britain that, even treated, AI continues to be associated with considerable morbidity, impaired quality of life (QoL) and reduced life expectancy (5). Indeed, the established glucocorticoid replacement regimens do not completely mirror the endogenous hormonal production and their monitoring is also made difficult by the lack of reliable biomarkers (6). As a matter of fact, several AI patients may be exposed to mild glucocorticoid excess with potential development of complications, such as diabetes mellitus, dyslipidemia, hypertension and fragility fractures leading to impaired QoL and increased all-risk mortality. These aspects are particularly relevant when AI does coexist with other diseases, such as growth hormone (GH) deficiency (GHD), hypogonadism and neoplasia, which may have per se a significant impact on morbidity and life expectancy of patients $(7,8)$.

Published by Bioscientifica Ltd. 
This review deals with pathophysiological and clinical aspects related to the risk of over-replacement therapy in patients with primary and secondary AI. Part of the review will be devoted to drug-induced AI as an emerging model of glucocorticoid over-replacement in the specific clinical context of hypogonadal patients with prostate cancer receiving abiraterone (9) and patients with adrenocortical carcinoma receiving mitotane (10). Full-text articles in the English language were selected from a PubMed search spanning 1994-January 2017, for keywords including 'adrenal insufficiency', 'cortisol replacement', 'glucocorticoid overtreatment', 'cardiovascular risk', 'osteoporosis', 'fractures', 'quality of life', 'mortality'. Reference lists in selected papers were also used to broaden the search.

\section{Physiology of the hypothalamic-pituitary- adrenal axis}

Adrenal glands secrete cortisol, aldosterone and androgens. Physiologically, the secretion of cortisol and androgens is under the dominant control of pituitary corticotropin (ACTH), whereas aldosterone is primarily regulated by the renin-angiotensin system. ACTH is synergistically synthesized and secreted in response to hypothalamic hormones corticotropin-releasing hormone $(\mathrm{CRH})$ and vasopressin $(\mathrm{ADH})$, and in turn, stimulates cortisol synthesis and release. ACTH has ultradian and circadian rhythmicity, with a nadir between 24:00 h and 02:00 h, rising to peak on waking, and then gradually falling throughout the day, except small rises after eating (11). Therefore, normal individuals have very low or undetectable levels of circulating cortisol at midnight; cortisol levels then increase overnight to peak early in the morning and then decline slowly throughout the day. Many stressors can break through this rhythm, particularly inflammatory or infective stress, severe hypotension and intense exercise.

Cortisol circulates in the blood mainly bound to a hepatic-derived cortisol-binding globulin, with approximately $5 \%$ free hormone being biologically active. Glucocorticoids exert their effects on responsive cells by binding to and activating a $90-\mathrm{kDa}$ intracellular glucocorticoid receptor protein. The peripheral activity of cortisol may be influenced by polymorphism of glucocorticoid receptor (12). Moreover, the cortisol availability to responsive cells is regulated by the enzyme $11 \beta$-hydroxysteroid dehydrogenase deputed to modulate the activation (i.e. transformation of cortisone in cortisol by type 1 enzyme) and inactivation (i.e. transformation of cortisol in cortisone by type 2 enzyme) of glucocorticoids in the target tissues (13).

States of hypoadrenalism and hyperadrenalism may impact on several neuroendocrine axes such as the hypothalamus-pituitary-gonadal axis as well as the GH-insulin-like growth factor-1 (IGF-1) axis, which is suppressed in both AI and hyperfunction $(14,15)$.

\section{Causes of Al}

\section{Primary Al}

Primary AI is caused by destruction or impaired function of adrenocortical cells. In western countries and in Japan, the most common cause of primary AI is autoimmune $(4,16)$, whereas tuberculosis is still predominant in developing countries $(4,17)$. Other causes of primary AI include bilateral adrenalectomy (a third-line option in Cushing disease), drugs (e.g. ketoconazole, rifampicin, mitotane), non-tubercular infections (e.g. histoplasmosis, cryptococcosis, paracoccidioidomycosis), genetic diseases and metastatic and hemorrhagic disorders $(4,18)$. Currently, primary AI is estimated to affect around 100000 individuals in Europe $(19,20)$, with a prevalence ranging from 93 to 221 cases/million and incidence estimated at 4-6 cases per million per year (18).

Mitotane (1-(2-chlorophenyl)-1-(4-chlorophenyl)-2,2dichloroethane,o,p0-DDD) is available for the treatment of adrenocortical carcinoma since decades (21), and it has a potent adrenolytic activity due to the o,p-DDD isomer (22). Sterol O-acyltransferase-1 inhibition by mitotane leads to intracellular accumulation of toxic lipids, which results in activation of the endoplasmic reticulum stress response and consequently results in reduced steroidogenesis and apoptosis of adrenal carcinoma cells (23). Mitotane has an irreversible and preferable binding with both zona fasciculata and zona reticularis in adrenal cortex (24), whereas the zona glomerulosa is relatively spared by the cytotoxic effect of this drug (21).

\section{Secondary Al}

AI may be secondary to ACTH deficiency due to pituitary and hypothalamic diseases including tumors, surgical hypophysectomy, head traumas, radiotherapy, autoimmune hypophysitis and empty sella (25). Furthermore, AI may be caused by iatrogenic suppression of hypothalamus-pituitary-adrenal axis as a consequence 
of high-dose steroid treatment abruptly being stopped (26) or as effect of chronic treatment with drugs targeting the nervous system, such as opioids $(27,28)$.

The prevalence of central hypoadrenalism is estimated around $125-280$ per million with up to onethird of patients with pituitary disease presenting this condition (29).

\section{Adrenal hyperplasia - congenital}

Congenital adrenal hyperplasia is a group of genetic disorders characterized by impaired cortisol synthesis due to inactivating mutations of key enzymes in the steroidogenetic process. The incidence ranges from 1:10000 to 1:20000 births (30) with a higher prevalence in some ethnic groups (e.g. Alaskan Yupiks). The most common form of congenital adrenal hyperplasia is caused by mutations in CYP21A2, the gene encoding the adrenal steroid 21-hydroxylase enzyme (31). This enzyme converts 17-hydroxyprogesterone to 11-deoxycortisol and progesterone to deoxycorticosterone, respective precursors for cortisol and aldosterone. Patients affected by the classical form of congenital adrenal hyperplasia caused by deficiency of 21-hydroxylase enzyme have deficiency of both cortisol and aldosterone. The cortisol synthetic block leads to ACTH stimulation of the adrenal cortex, with accumulation of cortisol precursors that are diverted to sex hormone biosynthesis resulting in prenatal virilization of girls and rapid somatic growth with early epiphyseal fusion in both sexes (31). More rarely, congenital adrenal hyperplasia is caused by deficiency of P450c17 enzyme, which sequentially catalyzes $17 \alpha$-hydroxylase and 17,20lyase reactions, which are essential for the production of glucocorticoids and sex steroids, respectively (32). In the adrenal gland, the lack of P450c17 enzyme activity decreases androgen and cortisol synthesis and stimulates the secretion of ACTH. Increased ACTH in turn promotes adrenal hyperplasia with excessive production of mineralocorticoids (11-deoxycorticosterone) upstream of $17 \alpha$-hydroxylase and C17,20-lyase defect leading to the development of hypertension and hypokalemia associated to sexual infantilism in males (32).

\section{Adrenal hyperplasia - acquired}

An emerging form of acquired adrenal hyperplasia is that induced by abiraterone in patients with prostate cancer. Abiraterone is a potent, selective and irreversible inhibitor of $17 \alpha$-hydroxylase and C17,20-lyase currently used in patients with prostate cancer resistant to conventional androgen deprivation therapy with GnRH agonists (33, $34)$. As in the congenital form of adrenal hyperplasia, the inhibition of $17 \alpha$-hydroxylase and C17,20-lyase by abiraterone is accompanied by androgen and cortisol insufficiency accompanied by excessive production of mineralocorticoids (11-deoxycorticosterone) upstream of enzymatic block. Other anti-androgen agents used in the treatment of advanced prostate cancer such as enzalutamide (which is commercially available) and other molecules still undergoing clinical development do not interfere with adrenal hormone synthesis $(35,36)$.

\section{Treatment options of Al: conventional and emerging therapeutic regimens}

AI could be theoretically treated with different types of glucocorticoids. Indeed, the European Adrenal Insufficiency Registry observational study showed a significant heterogeneity in the type, dose, frequency and timing of glucocorticoid replacement of primary and secondary AI in real-life clinical practice (37).

\section{Hydrocortisone and cortisone acetate}

In many countries, hydrocortisone is available as 10 or $20 \mathrm{mg}$ tablets or $2.5 \mathrm{mg}$ pellets. In countries where hydrocortisone is not easily available, $25 \mathrm{mg}$ tablets of cortisone acetate are used to replace AI. Cortisone acetate is a pro-hormone that needs to be converted in hydrocortisone via the hepatic 11ß-hydroxysteroid dehydrogenase type 1 . The glucocorticoid activity of cortisone acetate is equivalent to 0.8 of hydrocortisone. Hydrocortisone has short half-life (approximately $90 \mathrm{~min}$ ) (38), and multiple dosing is recommended to try mimicking the physiological conditions. The first and largest dose is suggested to be given upon awakening, the next either in the early afternoon ( $2 \mathrm{~h}$ after lunch; two-dose regimen) or at lunch and afternoon (three dose regimen) $(39,40)$, to avoid an overexposure to cortisol during early hours of the night when physiological cortisol secretion is barely detectable (41). The absorption curve of cortisone acetate is less steep and delayed as compared to hydrocortisone favoring a longer half-life (42). Therefore, cortisone acetate can be administered in two doses with the largest one in the morning and the smallest one in the early afternoon (40). These therapeutic regimens are applied to all patients with AI regardless of being primary or secondary. 


\section{Prednisone and dexamethasone}

Dexamethasone is readily absorbed after oral administration achieving peak plasma concentrations after one hour and the biological half-life is approximately 36-54h. Prednisone is a glucocorticoid prodrug that is converted by $11 \beta$-hydroxysteroid dehydrogenase in the liver into the active form, prednisolone. It is rapidly absorbed across gastrointestinal membrane, and it shows a peak effect after $1-2 \mathrm{~h}$ with a biological half-life of $18-36 \mathrm{~h}$.

Clinicians should remember that prednisone and dexamethasone have five and 30- to 50-fold greater glucocorticoid activity as compared to hydrocortisone, respectively. Prednisone exerts $80 \%$ of the mineralocorticoid activity of cortisol while dexamethasone has no mineralocorticoid activity. When long-acting glucocorticoids are used, one daily dose around $5 \mathrm{mg}$ of prednisone and $0.5 \mathrm{mg}$ of dexamethasone is sufficient to replace cortisol insufficiency $(30,40)$. However, even when used at equivalent physiological doses, prednisone and dexamethasone may potentially cause unfavorable effects due to their long half-life not resembling the physiological daily curve of cortisol.

\section{New formulations of hydrocortisone}

Dual-release hydrocortisone consists of an immediaterelease coating surrounding an extended-release core (43). When administered once daily upon awakening, dual-release hydrocortisone provides high levels of cortisol during the morning, followed by a gradual decrease throughout the day, thereby mimicking normal cortisol secretion more closely than conventional therapy (43).

Chronocort is another modified-release hydrocortisone formulation consisting of uniform multiparticulate beads, which have an inert core, a hydrocortisone drug layer and a delayed-release enteric outer coat that has a $\mathrm{pH}$ trigger of 6.8 allowing small bowel dissolution. This drug when administered twice-daily (i.e. $10 \mathrm{mg}$ at $07: 00 \mathrm{~h}$ and $20 \mathrm{mg}$ at 23:00 h) approximated physiologic cortisol rhythm replacing the rise in cortisol levels during the early hours of the morning (44), which is not mimicked by conventional formulations and the dual-release hydrocortisone.

\section{Primary Al}

Patients with AI require lifelong glucocorticoid replacement. The current guidelines recommend using hydrocortisone or cortisone acetate to replace primary or secondary $\operatorname{AI}(25,29,30,40)$, whereas other glucocorticoids are not usually used for this purpose. The daily dose of glucocorticoids to replace AI has been critically revised over the last 40 years. Based on radioisotope evaluation of endogenous cortisol production, former studies considered as physiological $30 \mathrm{mg}$ of hydrocortisone (45). Modern techniques measuring cortisol production rates suggest that the mean total daily production by adrenal glands is $5-8 \mathrm{mg} / \mathrm{m}^{2}$ body surface of cortisol, which approximates to a total daily dose of $15-20 \mathrm{mg}$ of hydrocortisone or $18-25 \mathrm{mg}$ of cortisone acetate $(46,47)$. When the dose was adjusted by body weight (i.e. $0.12 \mathrm{mg} / \mathrm{kg}$ per day), the cortisol profiles were shown to be more physiological as compared to the fixed dose regimens (48).

In most patients with primary AI, mineralocorticoid replacement with fludrocortisone is required to replace the inability of adrenal gland to synthesize aldosterone $(30,40)$.

Since the adrenals are heavily involved in the hormonal response to stress, the glucocorticoid replacement dose must be increased by two-three times in stressful conditions, such as fever, trauma, surgical interventions or intercurrent illness. In the case of vomiting or diarrhea, glucocorticoids must be administered intramuscularly or intravenously (40).

In mitotane-induced primary AI, patients require supraphysiological glucocorticoid supplementation owing to an increased metabolic clearance rate of glucocorticoids and enhanced production of cortisol-binding globulin induced by this drug $(21,22)$.

\section{Secondary Al}

Replacement therapy of secondary AI had the following peculiarities:

- Mineralocorticoid replacement therapy is not required in patients with secondary AI in whom renin-angiotensin-aldosterone axis is preserved $(25,29)$.

- Dose of hydrocortisone is often lower in secondary vs primary AI (49). The dose for glucocorticoid replacement may also be influenced by the residual ACTH secretion, concomitant therapies and diseases $(25,29)$. In fact, patients with hypopituitarism under treatment with recombinant human GH and estrogens may need higher glucocorticoid dose as compared to patients in whom GHD and hypogonadism are not 
replaced. This reflects the inhibitory effects of GH on 11ß-hydroxysteroid dehydrogenase type 1 responsible for the activation of cortisone in cortisol (25) and the decrease of cortisol bioavailability induced by estrogens (4).

\section{Adrenal hyperplasia - congenital}

In patients with congenital adrenal hyperplasia, glucocorticoid therapy has the dual purpose to replace cortisol insufficiency and inhibit the compensatory increase of ACTH (30). Long-acting glucocorticoids, such as prednisone and dexamethasone, may be used in patients with adrenal hyperplasia with the aim to better control ACTH values and suppress hypersecretion of adrenal hormones upstream the enzymatic defect (30). Indeed, there are no randomized controlled studies on long-term effects of different types of treatment in adults affected by classic congenital adrenal hyperplasia. The European Society for Paediatric Endocrinology (ESPE) survey found out that $36 \%$ of clinicians used hydrocortisone (mean dose $\left.13.75 \mathrm{mg} / \mathrm{m}^{2}\right), 14 \%$ used prednisolone $(4.75 \mathrm{mg} /$ daily) and $33 \%$ used dexamethasone $(0.5 \mathrm{mg} /$ daily) as treatment in patients with congenital adrenal hyperplasia (50). Mineralocorticoids are contraindicated in patients with deficiency of 17 $\alpha$-hydroxylase and C17,20-lyase, since mineralocorticoid synthesis is increased in this clinical condition $(9,32)$.

\section{Adrenal hyperplasia - acquired}

As previously mentioned, abiraterone administration mimics pharmacologically the congenital adrenal hyperplasia due to $17 \alpha$-hydroxylase deficiency. Therefore, abiraterone must be given in combination with glucocorticoids in order to avoid reduction in serum cortisol, the consequent increase in ACTH and the accumulation of steroids with mineralocorticoid properties (51). However, in mice, abiraterone is converted by an enzyme to the more active $\Delta 4$-abiraterone, which blocks multiple steroidogenic enzymes with a final more marked adrenal secretion inhibition and no increase in mineralcorticoid production (52). In this setting, the steroid supplementation would only have the aim of replacing cortisol deficiency. Nevertheless, the endogenous production of $\Delta 4$-abiraterone in treated patients is quite variable, and therefore, patients under abiraterone treatment are given prednisone at doses of
$5 \mathrm{mg}$ in the morning and in the evening to compensate cortisol insufficiency and to prevent ACTH increase (9). However, although this therapeutic regimen normalizes ACTH secretion preventing the increase in steroids with mineralcorticoid activity, it does not resemble the circardian rhythm of cortisol and the dose of prednisone used for this purpose is a half to twofold higher than that required to physiologically replace AI. Recently, a prospective randomized multinational phase II trial was conducted (NCI study number: NCT01867710) in one hundred sixty-four consecutive metastatic prostate cancer patients with asymptomatic, chemotherapy-naïve, castration-resistant disease. They were randomized to receive abiraterone in association with prednisone at one of three different dose schedules: $5 \mathrm{mg}$ twice-daily (Bis In Die; BID), $5 \mathrm{mg}$ once daily, $2.5 \mathrm{BID}$ or dexamethasone $0.5 \mathrm{mg}$ once daily. The preliminary results of this study presented as a meeting abstract (53) suggested that during 24 weeks of treatment with abiraterone, $5 \mathrm{mg}$ prednisone BID and DEX $0.5 \mathrm{mg}$ once daily both adequately controlled mineralcorticoid excess induced by abiraterone. Prednisone either 2.5 BID or $5 \mathrm{mg}$ once daily were efficacious but required adequate monitoring, especially for patients with high systolic blood pressure or pre-existing hypertension at baseline. No data are available on the potential side effects of these regimens in this short-term study period. No studies have been performed using hydrocortisone or cortisone acetate in addition to abiraterone therapy.

\section{Clinical consequences of glucocorticoid overtreatment}

Notwithstanding the current use of lower daily doses of glucocorticoids as compared to the past, the conventional therapeutic regimens of AI do not perfectly mimic the circadian rhythm of cortisol secretion resulting in a nonphysiological pattern of hormone peaks during the day (6). This may also be due to the persistent challenges in monitoring treatment; as a matter of fact, there is still no universal agreement on how to perform it. Still, many clinicians base dose changes on clinical parameters. Rousseau et al. suggested that a single point plasma of cortisol over $402 \mathrm{nmol} / \mathrm{L}$ as measured at $10: 00 \mathrm{~h}$ may predict over-replacement under standardized conditions of hydrocortisone administration (54). This finding was not confirmed by others (55). The use of urinary free cortisol levels is limited by a high inter-individual variability, and 
with this method, it is not possible to identify fluctuations of serum cortisol levels throughout the day (56). Moreover, urinary cortisol values may be impacted by the saturation of cortisol-binding protein that is influenced by the dose distribution of hydrocortisone replacement therapy (57). Specifically, urinary cortisol values were lower when hydrocortisone daily dose was fractioned as compared to the single dose administration. More recently, salivary cortisol measurements have been used, but also with this method, a high inter-individual variability as well as a poor correlation with plasma measurements is observed (58). Measurement of scalp hair cortisol concentrations has been proposed as another tool to evaluate the exposure of patients to hydrocortisone overtreatment over much longer periods of time (months to years) than possible with samples of blood, saliva or urine $(59,60)$. Finally, it is almost impossible to biochemically monitor the adequacy of the substitutive regimens with steroid different from hydrocortisone or cortisone acetate.

As a matter of fact, an overtreatment may occur in several patients treated with AI (5). Patients may not show clinical features of overt hypercortisolism and clinicians traditionally consider such mild glucocorticoid excess to have little clinical relevance. Indeed, during the last years, several studies have provided convincing data that over-replacement of AI may be associated with high risk of cardiovascular (CV) and bone complications (Fig. 1), impaired QoL and increased mortality. In the following sections, we will summarize the evidence on which these assumptions are based.

\section{Cardiovascular (CV) risk}

Glucocorticoids are known to have permissive activity on vasoactive agents, such as angiotensin II and catecholamines (61). Moreover, at high doses, glucocorticoids have access to mineralcorticoid receptor in the kidney due to saturation of $11 \beta$-hydroxysteroid dehydrogenase type 2 isoenzyme. Therefore, hypertension frequently occurs in patients under long-term treatment with corticosteroids (Fig. 1) (62).

Glucocorticoids are also known to affect glucose metabolism (63) (Fig. 1). They increase hepatic gluconeogenesis, inhibit peripheral glucose utilization and promote hepatic glycogen synthesis by making substrates available for an acute stress response. Moreover, glucocorticoids inhibit insulin production leading to a pancreatic $\beta$-cell dysfunction, which may be an important contributing factor to the development of glucose intolerance and diabetes in patients exposed to glucocorticoid excess (63). Diabetes and glucose intolerance are frequent complications of glucocorticoid excess, even when hypercortisolism is mild and 'subclinical' (63).

Glucocorticoids have complex, still not fully elucidated effects on lipid metabolism, including direct and indirect actions on lipolysis, free fatty acid production and turnover, very-low-density lipoproteins synthesis and fatty accumulation in liver (64) (Fig. 1). A positive correlation exists between plasma low-density lipoprotein (LDL) cholesterol and endogenous plasma cortisol in healthy men (65). Five studies, including

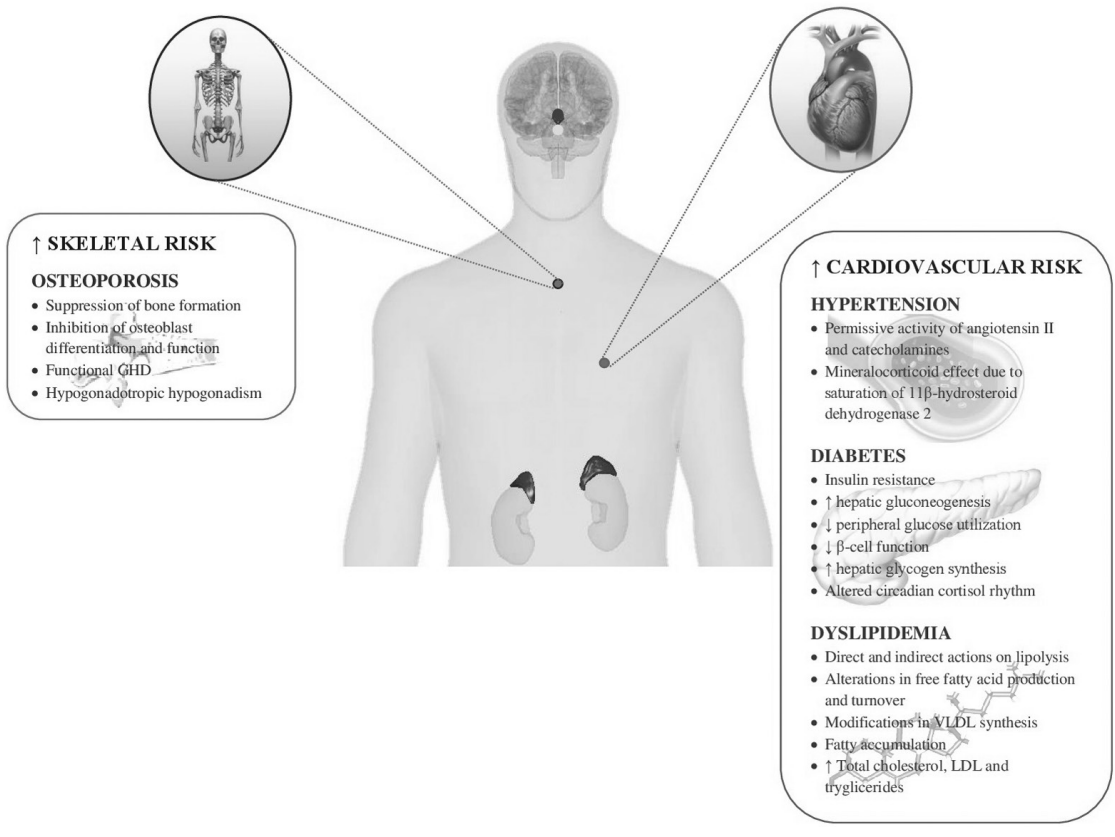

Figure 1

Schematic representation of complications of adrenal insufficiency overtreatment and related mechanisms. GHD, growth hormone deficiency; LDL, low-density lipoproteins; VLDL, very-low-density lipoproteins. 
Table 1 Effects of conventional glucocorticoid replacement regimens on cardiovascular risk in patients with adrenal insufficiency (Al).

\begin{tabular}{|c|c|c|c|}
\hline Author, year & Pts. & PAI/SAI/CAH & Study design \\
\hline Filipsson, 2006 (66) & 2424 & $0 / 2424 / 0$ & Retrospective, cross-sectional \\
\hline Ross, 2014 (69) & 110 & $110 / 0 / 0$ & Cross-sectional \\
\hline Bouvattier, 2015 (67) & 219 & $0 / 0 / 219$ & Retrospective, cross-sectional \\
\hline Werumeus Buning, 2016 (70) & 47 & $0 / 47 / 0$ & Prospective, randomized \\
\hline Quinkler, 2017 (68) & 188 & 75/113/0 & Retrospective, cross-sectional \\
\hline
\end{tabular}

$\mathrm{BMI}$, body mass index; CA, cortisone acetate; CAH, congenital adrenal hyperplasia; DEX, dexamethasone; DBP, diastolic blood pressure; HC, hydrocortisone; HDL-C, high-density lipoprotein cholesterol; LDL-C, low-density lipoprotein cholesterol; PAl, primary adrenal insufficiency; PDN, prednisolone; Pts., patients; SAI, secondary adrenal insufficiency; SBP, systolic blood pressure; T-COL, total cholesterol; TG, triglycerides; W/H, waist/hip ratio.

2988 patients, specifically evaluated the effects of conventional glucocorticoid replacement therapy on $\mathrm{CV}$ risk in AI patients; 3 studies were retrospective $(66,67$, 68 ), one cross-sectional (69) and one prospective (70) (Table 1).

\section{Primary Al}

Patients with primary AI under conventional treatment showed high $\mathrm{CV}$ risk profile characterized by higher prevalence of central adiposity, impaired glucose tolerance and a trend toward an increased risk of dyslipidemia (71). Similar findings were observed in patients treated with 3-6 mg daily of prednisolone, whereas a significant improvement of lipid profile was observed when patients were treated with hydrocortisone at doses lower than $30 \mathrm{mg}$ per day (68). However, there is evidence that other factors, such as genetic background and lifestyle, may influence the $\mathrm{CV}$ risk regardless of corticosteroid doses. In fact, South African patients with primary AI exhibited a more atherogenic lipid profile, despite being exposed to lower daily hydrocortisone doses, in comparison with Swedish AI patients (69).

In patients with AI under conventional therapeutic regimen, disorders of glucose homeostasis seem to be correlated with the altered circadian rhythm of cortisol more than with the total daily dose $(72,73)$. In fact, glucose homeostasis did not change significantly reducing hydrocortisone daily dose, but it significantly improved when replacement therapy was performed using the dualrelease hydrocortisone with more physiological cortisol profile during the day (see 'Future directions' section). Patients with autoimmune AI may develop type 1 diabetes in the context of autoimmune polyendocrine syndrome type 2; in these cases, glucocorticoid replacement therapy may influence the amount of insulin needed and the glycometabolic control (74).

The effects of glucocorticoid therapy on blood pressure in primary AI are still a matter of uncertainty, since a recent study provided evidence that genetic background more than hydrocortisone dose may influence the risk of hypertension in this clinical setting (69). However, the observation that systolic and diastolic blood pressure increased after switching from low to high dose of hydrocortisone (70) and improved after switching from conventional to dual-release hydrocortisone therapy (72) suggests that daily exposure to cortisol may also influence blood pressure in patients with AI.

\section{Secondary Al}

Hypopituitarism is a clinical condition characterized by the presence of several traditional and emerging $\mathrm{CV}$ risk factors, which can significantly increase CV morbidity and mortality. So far, most of the studies in hypopituitary patients took into consideration primarily the role of GHD, noticing an alteration not only of lipid profile and blood pressure, but also an increase in pro-inflammatory cytokines $(75,76)$. Also, in secondary AI, the increase in blood pressure due to glucocorticoid over-replacement may lead to an increase in CV deaths (77). Indeed, a recent observational study showed higher risk of hyperlipidemia and hypertension in secondary as compared to primary AI and congenital adrenal insufficiency (78). Moreover, the dose of hydrocortisone was shown to be closely correlated with higher blood pressure (70) and hydrocortisone doses higher than $20 \mathrm{mg}$ per day were associated with an unfavorable metabolic profile characterized by increased serum levels of total cholesterol, LDL cholesterol and triglycerides and higher body mass index after adjustment 
for sex and age (66). Interestingly, reducing hydrocortisone dose by $50 \%$ was accompanied by improvement of body composition and lipid profile (66). Moreover, patients treated with prednisone showed worst body composition (66) and higher LDL cholesterol (68) as compared to patients treated with hydrocortisone.

\section{Adrenal hyperplasia}

High prevalence of obesity, diabetes and hyperlipidemia was found in patients with congenital adrenal hyperplasia as compared to control subjects $(79,80)$. Moreover, the relative risk of diabetes was higher in congenital adrenal hyperplasia as compared to the other forms of AI (78). Interestingly, also $\mathrm{CV}$ diseases, such as atrial fibrillation and thromboembolism occurred, at increased rates in these patients (80). Indeed, the inherent hormonal imbalances of hyperandrogenism and glucocorticoid deficiency may be important in the pathophysiology of the increased $\mathrm{CV}$ risk in patients with congenital adrenal hyperplasia. In fact, a strong negative correlation between abdominal adiposity and sex hormone-binding protein was noted and the physiological differences in visceral adiposity between males and females were lost in congenital adrenal hyperplasia (79). However, an important role may also be exerted by the supraphysiological glucocorticoid replacement, although the retrospective design of the available studies did not allow to clarify the specific impact of glucocorticoid over-replacement on CV morbidity. In fact, doses of corticosteroids were usually reported only at the time of the study and the cumulative dose during the entire treatment period was not specified. However, it is noteworthy that male patients with congenital adrenal hyperplasia treated with dexamethasone showed higher body mass index than patients receiving hydrocortisone (67), suggesting that the daily glucocorticoid exposure may have an impact on body composition and then on $\mathrm{CV}$ risk.

An open issue is also whether treatment of congenital adrenal hyperplasia may cause hypertension. One study reported lower blood pressure values in patients with treated congenital adrenal hyperplasia as compared to reference population (67), whereas other studies showed higher risk of hypertension, visceral obesity, atrial fibrillation, venous thromboembolism, diabetes and hyperlipidemia in patients with congenital adrenal hyperplasia as compared to control population $(78,79,80)$. The low prevalence of hypertension in some experiences may likely reflect the preferential use of hydrocortisone vs long-acting corticosteroids (67).

\section{Skeletal fragility}

Glucocorticoids exert multiple undesired effects on bone health (81) (Fig. 1). The central pathophysiological mechanism of glucocorticoid-induced osteoporosis is the suppression of bone formation, due to inhibitory effects of glucocorticoids on osteoblast differentiation and function, accounting for chronic impairment of bone quality and disproportionate loss of bone strength in relation to bone mass in this form of secondary osteoporosis (82). Besides the direct effects on bone cells, glucocorticoids may also have indirect effects mediated by derangements in neuroendocrine signals (83). The effects of glucocorticoids on GH secretion are worthy to be mentioned since both AI and glucocorticoid excess may impair GH secretion $(14,15)$. Interestingly, low circulating levels of glucocorticoids, as they occur in untreated AI, cause a functional impairment of $\mathrm{GH}$ secretion which is rapidly reverted by restoring normal cortisol values ('Giustina effect') $(15,84,85)$. However, when glucocorticoid levels exceed the physiological range, an increase in hypothalamic somatostatin tone may occur with consequent impairment of GH secretion $(86,87,88)$. This inhibitory effect on pituitary GH secretion was observed even when the glucocorticoid excess was mild, as in patients with subclinical hypercortisolism (89). Glucocorticoids may also have effects on sex hormones production (83). Specifically, glucocorticoids inhibit the release of gonadotropins with consequent secondary hypogonadism. However, the real impact of GHD and hypogonadism on skeletal fragility in patients with treated AI is still largely unknown since no studies have specifically investigated the incidence and functional relevance of neuroendocrine derangements in untreated and treated $\mathrm{AI}(86)$. However, there is some literature evidence that GHD may influence the effects of glucocorticoid replacement therapy in patients with secondary AI (see below).

Nine studies, including 743 patients, were considered for evaluation of conventional glucocorticoid replacement therapy effects on skeletal health in patients with AI (Table 2). Seven studies were cross-sectional (90, 91, 92, $93,94,95,96)$ and 2 were prospective $(97,98)$.

\section{Primary Al}

Data on skeletal health in primary AI are inconsistent and even contradictory, with studies reporting low BMD and other reporting normal densitometric values $(4,5$, 18). Different factors may influence the heterogeneity of 
Table 2 Effects of conventional glucocorticoid therapeutic regimens on skeletal health in patients with adrenal insufficiency (Al).

\begin{tabular}{|c|c|c|c|}
\hline Author, year & Pts. & PAI/SAI/CAH & Study design \\
\hline Zelissen, 1994 (90) & 91 & $91 / 0 / 0$ & Cross-sectional \\
\hline Peacey, 1999 (97) & 12 & $6 / 6 / 0$ & Prospective \\
\hline Jodar, 2003 (91) & 25 & $25 / 0 / 0$ & Cross-sectional \\
\hline Løvås, 2009 (92) & 292 & $292 / 0 / 0$ & Cross-sectional \\
\hline Mazziotti, 2010 (93) & 41 & $0 / 41 / 0$ & Cross-sectional \\
\hline Koetz, 2012 (94) & 122 & $81 / 0 / 41$ & Cross-sectional \\
\hline Falhammar, 2013 (95) & 32 & $0 / 0 / 32$ & Cross-sectional \\
\hline Ceccato, 2016 (96) & 38 & $0 / 0 / 38$ & Cross-sectional \\
\hline Schulz, 2016 (98) & 90 & $57 / 0 / 33$ & Prospective \\
\hline
\end{tabular}

Main results

$\downarrow$ LS BMD (in relationship with HC dose in men) $\downarrow$ or $\uparrow$ LS BMD after decreasing HC dose

$\uparrow$ Osteoporosis (PDN vs HC)

$\downarrow$ FN and LS BMD (PAI vs reference population, in relationship with $\mathrm{HC}$ dose); $\leftrightarrow$ VFs

$\uparrow$ VFs (untreated GHD and over-treated SAI vs treated GHD)

Bone turnover markers, LS and FN BMD (PDN vs HC)

$\uparrow$ Osteoporosis (PDN vs HC)

$\downarrow$ FN BMD (CAH vs controls); no correlation with GC dose

$\uparrow \mathrm{TH}$ and LS BMD after decreasing HC dose; $\downarrow$ FN BMD after increasing $\mathrm{HC}$ dose

BMD, bone mineral density; CAH, congenital adrenal hyperplasia; FN, femoral neck; GC, glucocorticoid; GHD, growth hormone deficiency; HC, hydrocortisone; LS, lumbar spine; PAI, primary adrenal insufficiency; PDN, prednisolone; Pts., patients; SAI, secondary adrenal insufficiency; TH, total hip; VFs, vertebral fractures.

BMD results in this clinical setting, such as different study designs and populations, genetic variability, androgen status and type and/or dose of corticosteroids used to replace AI. Interestingly, low BMD values were associated with polymorphism of $r$ s1045642 in the efflux transporter P-glycoprotein, which was shown to cause impaired function of this protein with consequent increment in intracellular cortisol levels and higher sensitivity to glucocorticoid therapy (92). Moreover, androgen deficiency may influence skeletal health in this clinical setting although higher BMD values in relationship with dehydroepiandrosterone (DHEA) therapy were reported in only one small study (94). In cross-sectional studies, BMD was shown to be inversely correlated with hydrocortisone daily doses $(90,92)$. Moreover, BMD values at femoral neck and lumbar spine were lower and the rate of osteoporosis was higher in patients treated with prednisolone as compared to those treated with hydrocortisone at equivalent doses $(91,94)$. The skeletal impact of optimization of corticosteroid replacement therapy was investigated by two prospective studies $(97,98)$. In the first study performed in a small and heterogeneous population of patients with primary and secondary AI, the decrease of hydrocortisone dose from 30 to $20 \mathrm{mg}$ per day led to mixed results with some patients improving their BMD and other continuing to lose bone (97). More consistent results were obtained by the other prospective study in which the decrease in hydrocortisone dose was accompanied by a significant improvement in BMD at lumbar spine and total hip, whereas a further decrease in femoral neck BMD was shown in those patients in whom corticosteroid doses were increased (98).

BMD is not a reliable predictor of fracture risk in patients exposed to glucocorticoid excess (83), similarly to other forms of secondary osteoporosis $(99,100$, 101). However, data on fractures in patients treated with glucocorticoids for AI are scanty and somehow controversial. Higher frequency of hip fractures was observed in patients with primary AI, but the specific effects of glucocorticoid over-replacement on this outcome was uncertain as the fracture risk was reported to be highest in the first year after diagnosis of adrenal disease (102). Prevalence of radiological vertebral fractures was found to be not increased in a small series of patients with primary AI (92), although the study was not sufficiently powered to address this specific end point.

\section{Secondary Al}

Pituitary hormones have direct and indirect effects on bone remodeling, and low bone turnover and decreased BMD are frequently observed in patients with hypopituitarism. There has been evidence that GHD is the main determinant of skeletal fragility in patients with hypopituitarism (99) and replacement therapy of GHD was shown to normalize the fracture risk (103). In this context, treatment of AI with hydrocortisone doses higher than $28 \mathrm{mg}$ per day was associated with higher prevalence of radiological vertebral fractures in adult males mainly when GHD was not replaced (93), consistently with the physiological concept that in absence of GH glucocorticoids are overactivated at the peripheral tissue level (99).

\section{Adrenal hyperplasia}

Adult patients with congenital adrenal hyperplasia showed reduced BMD as compared to primary AI (94) and almost threefold increase in osteopenia/osteoporosis as 
compared to control subjects $(95,104)$. Consistently with the hypothesis that low BMD was caused by glucocorticoid overtreatment, decreased bone formation markers were reported in treated patients with congenital AI (95), as well as in those with primary AI. Interestingly, all patients with osteoporosis were taking prednisolone, whereas those taking hydrocorticosone or cortisone acetate showed better BMD values (95). Indeed, no correlation between glucocorticoid doses and BMD was observed $(96,104)$, although the markedly suppressed androgens reported in most of these patients may suggest that supraphysiological doses of corticosteroids may have caused bone loss (104). High prevalence of clinical fractures was reported in about $30 \%$ of women with congenital adrenal hyperplasia in close relationship with the age of patients (104).

The issue of skeletal fragility may be clinically relevant in patients with prostate cancer treated with abiraterone, in whom the detrimental effects of long-acting glucocorticoids used to replace cortisol insufficiency and reduce ACTH increase may be amplified by coexistent drug-induced hypogonadism and possible skeletal localization of cancer cells (81).

\section{Quality of life (QoL)}

Patients under replacement therapy for AI consistently self-report impairment in QoL by means of specific but also generic self-questionnaires $(5,18,105)$. Patient's Association membership, female gender, older age, presence of other autoimmune or inflammatory comorbidities, lower education and delayed diagnosis of AI, longer disease duration predicted impaired QoL $(106,107,108)$. Impaired QoL may occur due to affective and depressive disorders, which were shown to occur more frequently in AI $(108,109,110)$. Noteworthy, occupational changes due to AI were reported by $40 \%$ of interviewed patients and a variable degree of work disability was registered in about $20-30 \%$ of patients with AI $(108,111,112$, 113). Sleep disturbances, occurring as effect of disruption in the cortisol rhythm (114), may also play a role in influencing QoL in patients with primary AI (115). Patients with secondary AI showed more pronounced impairment of QoL and more frequent working disability as compared to patients with primary AI (111), likely reflecting the potential impact of hypopituitarism on these clinical outcomes (116). Patients with congenital adrenal hyperplasia showed a better QoL as compared to primary AI (117). Indeed, reports of QoL in congenital adrenal hyperplasia are inconsistent since variable results have been provided by the several studies published on this topic (118). One could argue that the apparently better QoL in patients with congenital adrenal hyperplasia may derive from the fact they have never experienced a time without their disorder (118). However, it is worthy to be mentioned that some patients with congenital adrenal hyperplasia may refer impaired QoL in relationship with the dose of corticosteroids, use of longacting formulations and increase adiposity and insulin resistance $(118,119,120)$.

The impact of replacement regimens on QoL has been specifically investigated by 12 studies including 3844 patients (Table 3). Six studies were prospective $(121,122,123,124,125), 5$ were cross-sectional (119, $120,127,128,129)$ and one was retrospective (130). Indeed, the results were controversial. Some studies did not report any association between corticosteroid doses and QoL $(121,123)$. Others, by contrast, reported more pronounced impairment of QoL in patients with primary and secondary AI receiving more than $20-30 \mathrm{mg}$ per day of hydrocortisone as compared to those treated with lower corticosteroid doses $(124,128,130)$. Moreover, an association between high hydrocortisone dose and high prevalence of inadequate personality traits and depression was also observed (129). On the other hand, two cross-over studies reported an impairment in QoL and pain after decreasing hydrocortisone doses (122, 126), suggesting that some patients may benefit from maintaining high dose of glucocorticoids for replacing AI. However, the results of cross-over studies may be influenced by carryover effect of glucocorticoids and also by eventual slow adaption of peripheral tissue sensitivity to rapid changes in drug doses. As a matter of fact, the improvement of self-reported well-being in patients treated with four-dose regimen of hydrocortisone (125) and in those switching from conventional therapeutic regimens to dual-release hydrocortisone $(72,73)$ suggests that a more physiological cortisol exposure may have some benefits on QoL, such as those demonstrated for other clinical outcomes.

\section{Mortality \\ Primary Al}

In population-based studies, the relative risk of death was increased by more than twofold in young adult patients with primary AI under replacement therapy in relationship with CV, malignant and infectious diseases, particularly 
Table 3 Effects of conventional glucocorticoid replacement regimens on quality of life (QoL) in patients with adrenal insufficiency (Al).

\begin{tabular}{|c|c|c|c|}
\hline Author, year & Pts. & PAI/SAI/CAH & Study design \\
\hline Wichers, 1999 (121) & 9 & $0 / 9 / 0$ & Prospective, randomized \\
\hline Alonso, 2004 (122) & 12 & $12 / 0 / 0$ & Prospective \\
\hline Bleicken, 2008 (127) & 427 & $232 / 195 / 0$ & Cross-sectional \\
\hline Bleicken 2010 (128) & 334 & $194 / 140 / 0$ & Cross-sectional \\
\hline Behan, 2011 (123) & 10 & $0 / 10 / 0$ & Prospective, randomized \\
\hline Benson, 2012 (124) & 18 & $0 / 18 / 0$ & Prospective, randomized \\
\hline Ekman, 2012 (125) & 15 & $15 / 0 / 0$ & Prospective, randomized \\
\hline Han, 2013 (120) & 151 & $0 / 0 / 151$ & Cross-sectional \\
\hline Falhammar, 2014 (119) & 30 & $0 / 0 / 30$ & Cross-sectional \\
\hline Ragnarsson, 2014 (130) & 2737 & $0 / 2737 / 0$ & Retrospective, longitudinal \\
\hline Tiemensma, 2014 (129) & 54 & $54 / 0 / 0$ & Cross-sectional \\
\hline Werumeus Buning, 2016 (126) & 47 & $0 / 47 / 0$ & Prospective, randomized \\
\hline
\end{tabular}

Main clinical outcomes

$\leftrightarrow$ QoL (high HC dose vs low HC dose)

$\uparrow$ QoL (high HC dose vs low HC dose)

$\leftrightarrow$ QoL (PDN vs HC and CA)

$\downarrow$ QoL (high HC dose vs low HC dose)

$\leftrightarrow$ QoL (high HC dose vs low HC dose)

$\downarrow$ QoL (high $\mathrm{HC}$ dose vs low $\mathrm{HC}$ dose)

$\uparrow$ QoL (4 doses of HC vs 2 doses of HC)

$\downarrow$ QoL (PDN/DXA vs HC)

$\downarrow$ QoL (overtreated vs poorly controlled and controls)

$\downarrow$ QoL (high HC dose vs low HC dose)

$\uparrow$ Inadequate personality traits and depression (high dose $\mathrm{HC}$ vs low dose $\mathrm{HC}$ )

$\uparrow$ QoL (high HC dose vs low HC dose)

$\mathrm{CAH}$, congenital adrenal hyperplasia; CA, cortisone acetate; HC, hydrocortisone; PAl, primary adrenal insufficiency; PDN, prednisolone; Pts., patients; SAI, secondary adrenal insufficiency.

when diabetes was coexistent (131). Noteworthy, most patients received high doses of cortisone acetate (i.e. higher than $37.5 \mathrm{mg}$ per day) (131). Another retrospective study showed increased mortality in patients (median aged 57; 0-85 years) with autoimmune polyendocrine syndrome type 1 , characterized by the coexistence of AI, hypoparathyroidism and chronic mucocutaneous candidiasis (132). When the survival analysis was performed by a prospective approach, no major increase in mortality rate was observed among patients with $\mathrm{AI}$ as compared to the general population, with the exception of young patients below 40 years of age in whom a twofold increase of standardized mortality ratio was shown mainly related to infections and sudden death besides acute adrenal crisis (133).

\section{Secondary Al}

Mortality is increased in patients with hypopituitarism, in relationship with untreated GHD, untreated hypogonadism and (over-) treated secondary AI $(77,134,135)$. Moreover, the risk of death from infectious diseases was 1.6-fold higher in patients with ACTH deficiency than that in those without ACTH deficiency (136) in close relationship with development of acute adrenal crisis in response to acute stress and intercurrent illness (137). Indeed, high incidence (i.e. 8.3 per 100 patient-years) of adrenal crisis was observed in patients with chronic AI receiving standard replacement therapy, even if well-educated to adjust glucocorticoid doses during critical illness (138). Noteworthy, about half of the sudden unexpected deaths occurring in patients with secondary AI was related to adrenal crises (139).

Patients with acromegaly and coexistent secondary AI were at increased risk of premature death when treated with hydrocortisone at a daily dose higher than $25 \mathrm{mg}$ compared to those receiving lower doses (7).

\section{Adrenal hyperplasia}

Mortality has been reported to be high in patients with congenital adrenal hyperplasia, although the impact of glucocorticoid overtreatment on this outcome is still uncertain (140).

In the pivotal trial (33), the combination therapy by abiraterone and prednisone led to a reduction in mortality compared to treatment with prednisone alone. Indeed, the specific role of glucocorticoid treatment on mortality of patients with prostate cancer under abiraterone treatment is still unknown. It is worth mentioning that glucocorticoids were hypothesized to favor progression of prostate cancer by reactivating adrenal receptor signaling in cancer cells exposed to androgen receptor blockade (141). On the other hand, glucocorticoids may have beneficial effects on symptoms of patients with prostate cancer (141).

\section{Conclusions and future directions}

Conventional hydrocortisone replacement regimens in the management of AI cannot provide the physiological 
rhythm of cortisol release and result in temporary over- or under-replacement (142), although most evidence on the unfavorable outcomes of conventional glucocorticoid regimens derives from retrospective and cross-sectional studies not allowing to reliably define specific recommendations. However, over the last years, pharmacologic research has developed new hydrocortisone formulations to potentially improve treatment of AI $(43,143,144)$, although their relative high cost and the limited availability in some countries do not yet permit the universal use of these drugs for treatment of AI. Interestingly, the more physiological serum cortisol resulting from this innovative treatment profile was accompanied by an improvement in several clinical outcomes of patients with primary and secondary $\operatorname{AI}(72,73,143,144,145,146,147)$. In fact, the use of dualrelease hydrocortisone was associated with reductions in body weight, glycated hemoglobin, and blood pressure and improvements in bone formation markers and QoL as compared to conventional therapeutic regimen either in head-to-head studies $(72,147)$ or in prospective evaluations performed in patients who were switched from conventional hydrocortisone replacement treatment to the dual-release hydrocortisone formulation $(72,73)$. Moreover, type 1 diabetes mellitus patients reduced their insulin requirement during dual-release hydrocortisone treatment (74). Interestingly, the daily doses of conventional regimen and dual-release hydrocortisone were similar, suggesting that for anthropometric and metabolic parameters, the improvement in serum cortisol profile was more important than reducing daily drug dose to prevent glucocorticoid overtreatment.

Congenital or acquired adrenal hyperplasia is a unique clinical model to investigate the effects of overreplacement therapy with glucocorticoids on different clinical outcomes since glucocorticoids are used for both hormonal replacement and suppression purposes (148). In a recent study, treatment with modified-release hydrocortisone (i.e. Chronocort) appeared to be superior to conventional glucocorticoid therapy in controlling androgen synthesis in patients with congenital adrenal hyperplasia (144), but the potential impact of this treatment on the clinical outcomes related to glucocorticoid over-replacement is still unknown.

Indeed, future randomized-blinded studies are needed to definitively confirm the potential advantages of the new formulations of hydrocortisone as compared to the conventional therapies in the different forms of hypoadrenalism. Moreover, studies will need to be powered to evaluate hard clinical end-points, such as major CV events, fragility fractures and mortality. In fact, the study design should take into account the peculiarities of clinical outcomes related to glucocorticoid overreplacement, such as the development of fragility fractures regardless of BMD values (83) and the predominant occurrence of glucocorticoid-induced hyperglycemia during the late afternoon or evening (63). Moreover, in evaluating QoL disease-specific questionnaires should be used and the effects of glucocorticoid overtreatment should be differentiated by those of comorbidities.

In the specific condition of abiraterone-induced AI, there are some peculiar aspects that need to be pointed out. Firstly, based on data provided by AI and congenital adrenal hyperplasia models, the currently used therapeutic regimen to suppress ACTH (i.e. $10 \mathrm{mg}$ of prednisone) provides a supraphysiologic glucocorticoid exposure. Abiraterone is currently administered in patients with castration-resistant prostate cancer that have a relatively limited survival perspective; therefore, the long-term effects of relatively excessive glucocorticoid exposure may not be particularly relevant. However, this risk becomes more clinically significant with the use of this drug in less advanced forms of prostate cancer with increased chances of long-term survival. From this point of view, longterm results of randomized clinical studies will show if prednisone supplementation at reduced doses ( $5 \mathrm{mg} /$ daily) may improve the tolerability (53). Probably, alternative glucocorticoids such as hydrocortisone to replace abiraterone-induced AI could be of value and deserve to be tested in the future. Secondly, it is conceivable that complete suppression of mineralcorticoid hypersecretion may likely not be needed in all patients since a residual synthesis of these hormones may be useful to compensate the cortisol insufficiency induced by abiraterone. On the other hand, the possible mineralcorticoid excess syndrome can be managed by mineralcorticoid receptor antagonists, as eplerenone (149). However, eplerenone can bind androgen receptors and can exert a stimulatory effect on prostate cancer growth, thus antagonizing the antiandrogen efficacy (150). Interestingly, novel non-steroidal compounds are currently in clinical development, and, due to their chemical structure, may not bind androgen receptors (151). In addition, amiloride selectively reduces the aldosterone-sensitive $\mathrm{Na}^{+} / \mathrm{K}^{+}$exchange, leading to increased urinary $\mathrm{Na}^{+}$excretion with relative $\mathrm{K}^{+}$sparing effects. Due to its non-steroidal chemical structure and the different mechanism of action, this drug does not interact with the androgen receptor and therefore it can be used in association with abiraterone. Preliminary data showed that the association of amiloride and hydrochlorothiazide 
is efficacious in the management of mineralcorticoid excess syndrome induced by abiraterone (152).

Finally, high-dose hydrocortisone replacement therapy is invariably needed in patients treated with mitotane for adrenocortical carcinoma; however, since the patients under this therapy frequently suffer from fatigue that is only partially due to hypocortisolism but improves with the increase in cortisone supplementation they are at risk of supraphysiologic glucocorticoid exposure. This issue is particularly relevant when mitotane is administered in the adjuvant setting in which the drug is recommended to be continued for a minimum of 2 years although there are no data regarding the optimal duration of this treatment (153). Studies testing the longterm effects of steroid supplementation with conventional and new hydrocortisone formulations during adjuvant mitotane are needed in the future (154).

\section{Declaration of interest}

G Mazziotti, S Frara, E Roca, P Mortini and A Berruti declare that there is no conflict of interest that could be perceived as prejudicing the impartially of the research reported. A M Formenti received consultant fees from Shire. A Giustina is a consultant for Astellas, Ipsen, Novartis, Pfizer and Shire.

\section{Funding}

This research was partially supported by G.I.O.S.E.G. (Glucocorticoidinduced osteoporosis and Skeletal Endocrinology Group).

\section{References}

1 Addison T. On the constitutional and local effects of disease of the supra-renal capsules. 1855. Reproduced in Dr. Addison's works. New Sydenham Society 186836 211-239.

2 Dunlop D. Eighty-six cases of Addison's disease. British Medical Journal 19632 887-891. (doi:10.1136/bmj.2.5362.887)

3 Hillier SG. Diamonds are forever: the cortisone legacy. Journal of Endocrinology 2007195 1-6. (doi:10.1677/JOE-07-0309)

4 Falorni A, Minarelli V \& Morelli S. Therapy of adrenal insufficiency: an update. Endocrine 201343 514-528. (doi:10.1007/s12020-012-9835-4)

5 Johannsson G, Falorni A, Skrtic S, Lennernäs H, Quinkler M, Monson JP \& Stewart PM. Adrenal insufficiency: review of clinical outcomes with current glucocorticoid replacement therapy. Clinical Endocrinology 201582 2-11. (doi:10.1111/cen.12603)

6 Debono M, Price JN \& Ross RJ. Novel strategies for hydrocortisone replacement. Best Practice Research in Clinical Endocrinology and Metabolism 20092 221-232. (doi:10.1016/j.beem.2008.09.010)

7 Sherlock M, Ayuk J, Tomlinson JW, Toogood AA, Aragon-Alonso A, Sheppard MC, Bates AS \& Stewart PM. Mortality in patients with pituitary disease. Endocrine Reviews 201031 301-342. (doi:10.1210/er.2009-0033)

8 Schneider HJ, Aimaretti G, Kreitschmann-Andermahr I, Stalla GK \& Ghigo E. Hypopituitarism. Lancet 200728 1461-1470. (doi:10.1016/S0140-6736(07)60673-4)

9 Auchus RJ, Yu MK, Nguyen S \& Mundle SD. Use of prednisone with abiraterone acetate in metastatic castration-resistant prostate cancer. Oncologist 201419 1231-1240. (doi:10.1634/ theoncologist.2014-0167)
10 Terzolo M, Ardito A, Zaggia B, Laino F, Germano A, De Francia S, Daffara F \& Berruti A. Management of adjuvant mitotane therapy following resection of adrenal cancer. Endocrine 201242 521-525. (doi:10.1007/s12020-012-9719-7)

11 Soto-Rivera CL \& Majzoub JA, Adrenocorticotrophin. In The Pituitary, 4 edition. Ed S Melmed. Elsevier, 2017. (doi:10.1016/ B978-0-12-380926-1.10003-3)

12 Giordano R, Marzotti S, Berardelli R, Karamouzis I, Brozzetti A, D'Angelo V, Mengozzi G, Mandrile G, Giachino D, Migliaretti $\mathrm{G}$ et al. BClI polymorphism of the glucocorticoid receptor gene is associated with increased obesity, impaired glucose metabolism and dyslipidaemia in patients with Addison's disease. Clinical Endocrinology 201277 863-870. (doi:10.1111/j.13652265.2012.04439.x)

13 Gathercole LL, Lavery GG, Morgan SA, Cooper MS, Sinclair AJ, Tomlinson JW \& Stewart PM. 11 $\beta$-Hydroxysteroid dehydrogenase 1: translational and therapeutic aspects. Endocrine Reviews 2013 34 525-555. (doi:10.1210/er.2012-1050)

14 Mazziotti G \& Giustina A. Glucocorticoids and the regulation of growth hormone secretion. Nature Reviews Endocrinology 20139 265-276. (doi:10.1038/nrendo.2013.5)

15 Giustina A \& Mazziotti G. Impaired growth hormone secretion associated with low glucocorticoid levels: an experimental model for the Giustina effect. Endocrine 201447 354-356. (doi:10.1007/ s12020-014-0278-y)

16 Betterle C, Dal Pra C, Mantero F \& Zanchetta R. Autoimmune adrenal insufficiency and autoimmune polyendocrine syndromes: autoantibodies, autoantigens, and their applicability in diagnosis and disease prediction. Endocrine Reviews 200223 327-364. (doi:10.1210/edrv.23.3.0466)

17 Kelestimur F. The endocrinology of adrenal tuberculosis: the effects of tuberculosis on the hypothalamo-pituitary-adrenal axis and adrenocortical function. Journal of Endocrinological Investigation 200427 380-386. (doi:10.1007/BF03351067)

18 Bensing S, Hulting AL, Husebye ES, Kämpe O \& Løvås K. Epidemiology, quality of life and complications of primary adrenal insufficiency: a review. European Journal of Endocrinology 2016175 R107-R116. (doi:10.1530/EJE-15-1242)

19 Laureti S, Vecchi L, Santeusanio F \& Falorni A. Is the prevalence of Addison's disease underestimated? Journal of Clinical Endocrinology and Metabolism 199984 1762. (doi:10.1210/jc.84.5.1762)

20 Løvas K \& Husebye ES. High prevalence and increasing incidence of Addison's disease in western Norway. Clinical Endocrinology 200256 787-791. (doi:10.1046/j.1365-2265.2002.t01-1-01552.x)

21 Daffara F, De Francia S, Reimondo G, Zaggia B, Aroasio E, Porpiglia F, Volante M, Termine A, Di Carlo F, Dogliotti L et al. Prospective evaluation of mitotane toxicity in adrenocortical cancer patients treated adjuvantly. Endocrine-Related Cancer 2008 15 1043-1053. (doi:10.1677/ERC-08-0103)

22 Hahner S \& Fassnacht M. Mitotane for adrenocortical carcinoma treatment. Current Opinion in Investigational Drugs 20056 386-394.

23 Sbiera S, Leich E, Liebisch G, Sbiera I, Schirbel A, Wiemer L, Matysik S, Eckhardt C, Gardill F, Gehl A et al. Mitotane inhibits sterol-o-acyl transferase 1 triggering lipid-mediated endoplasmic reticulum stress and apoptosis in adrenocortical carcinoma cells. Endocrinology 2015156 3895-3908. (doi:10.1210/en.2015-1367)

24 Lindhe O, Skogseid B \& Brandt I. Cytochrome P450-catalyzed binding of 3-methylsulfonyl-DDE and o,p'-DDD in human adrenal zona fasciculata/reticularis. Journal of Clinical Endocrinology and Metabolism. 200287 1319-1326. (doi:10.1210/ jcem.87.3.8281)

25 Grossman AB. Clinical review: the diagnosis and management of central hypoadrenalism. Journal of Clinical Endocrinology and Metabolism 201095 4855-4863. (doi:10.1210/jc.2010-0982)

26 Dinsen S, Baslund B, Klose M, Rasmussen AK, Friis-Hansen L, Hilsted L \& Feldt-Rasmussen U. Why glucocorticoid withdrawal 
may sometimes be as dangerous as the treatment itself. European Journal of Internal Medicine 20133 714-720. (doi:10.1016/j. ejim.2013.05.014)

27 Vuong C, Van Uum SH, O’Dell LE, Lutfy K \& Friedman TC. The effects of opioids and opioid analogs on animal and human endocrine systems. Endocrine Reviews 201031 98-132. (doi:10.1210/er.2009-0009)

28 Gibb FW, Stewart A, Walker BR \& Strachan MW. Adrenal insufficiency in patients on long-term opioid analgesia. Clinical Endocrinology 201685 831-835. (doi:10.1111/cen.13125)

29 Crowley RK, Argese N, Tomlinson JW \& Stewart PM. Central hypoadrenalism. Journal of Clinical Endocrinology and Metabolism 201499 4027-4036. (doi:10.1210/jc.2014-2476)

30 Speiser PW, Azziz R, Baskin LS, Ghizzoni L, Hensle TW, Merke DP, Meyer-Bahlburg HF, Miller WL, Montori VM, Oberfield SE et al. Endocrine Society. Congenital adrenal hyperplasia due to steroid 21-hydroxylase deficiency: an Endocrine Society Clinical Practice Guideline. Journal of Clinical Endocrinology and Metabolism 2010 95 4133-4160. (doi:10.1210/jc.2009-2631)

31 Falhammar H, Wedell A \& Nordenström A. Biochemical and genetic diagnosis of 21-hydroxylase deficiency. Endocrine $2015 \mathbf{5 0}$ 306-314. (doi:10.1007/s12020-015-0731-6)

32 Han B, Xue L, Fan M, Zhao S, Liu W, Zhu H, Cheng T, Lu Y, Cheng K, Song H et al. Clinical and molecular manifestation of fifteen 17OHD patients: a novel mutation and a founder effect. Endocrine 201653 784-790. (doi:10.1007/s12020-016-0957-y)

33 de Bono JS, Logothetis CJ, Molina A, Fizazi K, North S, Chu L, Chi KN, Jones RJ, Goodman OB Jr, Saad F et al. Abiraterone and increased survival in metastatic prostate cancer. New England Journal of Medicine 2011364 1995-2005.

34 Ryan CJ, Smith MR, de Bono JS, Molina A, Logothesis CJ, de Souza P, Fizazi K, Mainwaring P, Piulats JM, Ng S et al. Abiraterone in metastatic prostate cancer without previous chemotherapy. New England Journal of Medicine 2013368 138-148. (doi:10.1056/ NEJMoa1209096)

35 Beer TM, Armstrong AJ, Rathkopf DE, Loriot Y, Sternberg CN, Higano CS, Iversen P, Bhattacharya S, Carles J, Chowdhury S et al. Enzalutamide in metastatic prostate cancer before chemotherapy. New England Journal of Medicine 201431 424-433. (doi:10.1056/ NEJMoa1405095)

36 Jadhavar PS, Ramachandran SA, Riquelme E, Gupta A, Quinn KP, Shivakumar D, Ray S, Zende D, Nayak AK, Miglani SK et al. Targeting prostate cancer with compounds possessing dual activity as androgen receptor antagonists and HDAC6 inhibitors. Bioorganic and Medicinal Chemistry Letters 201626 5222-5228. (doi:10.1016/j.bmcl.2016.09.058)

37 Murray RD, Ekman B, Uddin S, Marelli C, Quinkler M, Zelissen PM \& EU-AIR Investigators. Management of glucocorticoid replacement in adrenal insufficiency shows notable heterogeneity - data from the EU-AIR. Clinical Endocrinology 201786 340-346. (doi:10.1111/cen.13267)

38 Czock D, Keller F, Rasche FM \& Häussler U. Pharmacokinetics and pharmacodynamics of systemically administered glucocorticoids. Clinical Pharmacokinetics 200544 61-98. (doi:10.2165/00003088200544010-00003)

39 Husebye ES, Allolio B, Arlt W, Badenhoop K, Bensing S, Betterle C, Falorni A, Gan EH, Hulting AL, Kasperlik-Zaluska A et al. Consensus statement on the diagnosis, treatment and follow-up of patients with primary adrenal insufficiency. Journal of Internal Medicine 2014275 104-115. (doi:10.1111/joim.12162)

40 Bornstein SR, Allolio B, Arlt W, Barthel A, Don-Wauchope A, Hammer GD, Husebye ES, Merke DP, Murad MH, Stratakis CA et al. Diagnosis and treatment of primary adrenal insufficiency: an Endocrine Society clinical practice guideline. Journal of Clinical Endocrinology and Metabolism 2016101 364-389. (doi:10.1210/jc.2015-1710)
41 Plat L, Leproult R, L'Hermite-Baleriaux M, Fery F, Mockel J, Polonsky KS \& Van Cauter E. Metabolic effects of short-term elevations of plasma cortisol are more pronounced in the evening than in the morning. Journal of Clinical Endocrinology and Metabolism 199984 3082-3092. (doi:10.1210/jc.84.9.3082)

42 Fariss BL, Hane S, Shinsako J \& Forsham PH. Comparison of absorption of cortisone acetate and hydrocortisone hemisuccinate. Journal of Clinical Endocrinology and Metabolism 197847 1137-1140. (doi:10.1210/jcem-47-5-1137)

43 Johannsson G, Bergthorsdottir R, Nilsson AG, Lennernas H, Hedner T \& Skrtic S. Improving glucocorticoid replacement therapy using a novel modified-release hydrocortisone tablet: a pharmacokinetic study. European Journal of Endocrinology 2009 161 119-130. (doi:10.1530/EJE-09-0170)

44 Whitaker MJ, Debono M, Huatan H, Merke DP, Arlt W \& Ross RJ. An oral multiparticulate, modified-release, hydrocortisone replacement therapy that provides physiological cortisol exposure. Clinical Endocrinology 201480 554-561. (doi:10.1111/cen.12316)

45 Cope CL \& Black E. The production rate of cortisol in man. British Medical Journal 19582 887-891. (doi:10.1136/bmj.2.5101.887)

46 Esteban NV, Loughlin T, Yergey AL, Zawadzki JK, Booth JD, Winterer JC \& Loriaux DL. Daily cortisol production rate in man determined by stable isotope dilution/mass spectrometry. Journal of Clinical Endocrinology and Metabolism 199172 39-45. (doi:10.1210/jcem-72-1-39)

47 Kerrigan JR, Veldhuis JD, Leyo SA, Iranmanesh A \& Rogol AD. Estimation of daily cortisol production and clearance rates in normal pubertal males by deconvolution analysis. Journal of Clinical Endocrinology and Metabolism 199376 1505-1510. (doi:10.1210/jc.76.6.1505)

48 Mah PM, Jenkins RC, Rostami-Hodjegan A, Newell-Price J, Doane A, Ibbotson V, Tucker GT \& Ross RJ. Weight-related dosing, timing and monitoring hydrocortisone replacement therapy in patients with adrenal insufficiency. Clinical Endocrinology 200461 367-375. (doi:10.1111/j.1365-2265.2004.02106.x)

49 Castinetti F, Sahnoun M, Albarel F, Morange I, Philippon M, Conte-Devolx B \& Brue T. An observational study on adrenal insufficiency in a French tertiary centre: real-life versus theory. Annales d'Endocrinologie 201576 1-8. (doi:10.1016/j. ando.2014.11.004)

50 Riepe FG, Krone N, Viemann M, Partsch CJ \& Sippell WG. Management of congenital adrenal hyperplasia: results of the ESPE questionnaire. Hormone Research 200258 196-205. (doi:10.1159/000065492)

51 Attard G, Reid AH, Auchus RJ, Hughes BA, Cassidy AM, Thompson E, Oommen NB, Folkered E, Dowsett M, Arlt $\mathrm{W}$ et al. Clinical and biochemical consequences of CYP17A1 inhibition with abiraterone given with and without exogenous glucocorticoids in castrate men with advanced prostate cancer. Journal of Clinical Endocrinology and Metabolism 201297 507-516. (doi:10.1210/jc.2011-2189)

52 Li Z, Bishop AC, Alyamani M, Garcia JA, Dreicer R, Bunch D, Liu J, Upadhyay SK, Auchus RJ \& Sharifi N. Conversion of abiraterone to D4A drives anti-tumour activity in prostate cancer. Nature 2015 523 347-351. (doi:10.1038/nature14406)

53 Attard G, Merseburger AS, Sternberg CN, et al. A randomized trial of abiraterone acetate (AA) administered with 1 of 4 glucocorticoid (GC) regimens in metastatic castration-resistant prostate cancer (mCRPC) patients (pts). Journal of Clinical Oncology 201634 (2_suppl; abstr 261).

54 Rousseau E, Joubert M, Trzepla G, Parienti JJ, Freret T, Vanthygem MC, Desailloud R, Lefebvre H, Coquerel A, Reznik Y et al. Usefulness of time-point serum cortisol and acth measurements for the adjustment of glucocorticoid replacement in adrenal insufficiency. PLOS ONE 201510 e0135975. (doi:10.1371/journal. pone.0135975) 
55 Arlt W, Rosenthal C, Hahner S \& Allolio B. Quality of glucocorticoid replacement in adrenal insufficiency: clinical assessment vs. timed serum cortisol measurements. Clinical Endocrinology $2006 \mathbf{6 4} 384-389$.

56 Trainer PJ, McHardy KC, Harvey RD \& Reid IW. Urinary free cortisol in the assessment of hydrocortisone replacement therapy. Hormone Metabolic Research 199325 117-120. (doi:10.105 5/s-2007-1002056)

57 Bliesener N, Steckelbroeck S, Redel L \& Klingmüller D. Dose distribution in hydrocortisone replacement therapy has a significant influence on urine free cortisol excretion. Experimental and Clinical Endocrinology and Diabetes $2003111443-446$. (doi:10.1055/s-2003-44292)

58 Thomson AH, Devers MC, Wallace AM, Grant D, Cambell K, Free M \& Connell JM. Variability in hydrocortisone plasma and saliva pharmacokinetics following intravenous and oral administration to patients with adrenal insufficiency. Clinical Endocrinology 2003 66 789-796. (doi:10.1111/j.1365-2265.2007.02812.x)

59 Wester VL \& van Rossum EF. Clinical applications of cortisol measurements in hair. European Journal of Endocrinology 2015173 M1-M10. (doi:10.1530/EJE-15-0313)

60 Hodes A, Lodish MB, Tirosh A, Meyer J, Belyavskaya E, Lyssikatos C, Rosenberg K, Demidowich A, Swan J, Jonas N et al. Hair cortisol in the evaluation of Cushing syndrome. Endocrine 2017 56 164-174. (doi:10.1007/s12020-017-1231-7)

61 Arnaldi G, Angeli A, Atkinson AB, Bertagna X, Cavagnini F, Chrousos GP, Fava GA, Findling JW, Gaillard RC, Grossman $\mathrm{AB}$ et al. Diagnosis and complications of Cushing's syndrome: a consensus statement. Journal of Clinical Endocrinology and Metabolism 200388 5593-5602. (doi:10.1210/jc.2003-030871)

62 Rossi GP, Seccia TM, Maniero C \& Pessina AC. Drug-related hypertension and resistance to antihypertensive treatment: a call for action. Journal of Hypertension 201129 2295-2309. (doi:10.1097/HJH.0b013e32834c465d)

63 Mazziotti G, Gazzaruso C \& Giustina A. Diabetes in Cushing syndrome: basic and clinical aspects. Trends in Endocrinology and Metabolism 201122 499-506. (doi:10.1016/j.tem.2011.09.001)

64 Arnaldi G, Scandali VM, Trementino L, Cardinaletti M, Appolloni G \& Boscaro M. Pathophysiology of dyslipidemia in Cushing's syndrome. Neuroendocrinology 201092 86-90. (doi:10.1159/000314213)

65 Nanjee MN \& Miller NE. Plasma lipoproteins and adrenocortical hormones in men - positive association of low density lipoprotein cholesterol with plasma cortisol concentration. Clinica Chimica Acta 1989180 113-120. (doi:10.1016/0009-8981(89)90342-2)

66 Filipsson H, Monson JP, Koltowska-Häggström M, Mattsson A \& Johannsson G. The impact of glucocorticoid replacement regimens on metabolic outcome and comorbidity in hypopituitary patients. Journal of Clinical Endocrinology and Metabolism 200691 3954-3961. (doi:10.1210/jc.2006-0524)

67 Bouvattier C, Esterle L, Renoult-Pierre P, de la Perrière AB, Illouz F, Kerlan V, Pascal-Vigneron V, Drui D, Christin-Maitre S, Galland F et al. Clinical outcome, hormonal status, gonadotrope axis, and testicular function in 219 adult men born with classic 21-hydroxylase deficiency. A French National Survey. Journal of Clinical Endocrinology and Metabolism $20151002303-2313$. (doi:10.1210/jc.2014-4124)

68 Quinkler M, Ekman B, Marelli C, Uddin S, Zelissen P \& Murray R. Prednisolone is associated with a worse lipid profile than hydrocortisone in patients with adrenal insufficiency. Endocrine Connection 20176 1-8. (doi:10.1530/EC-16-0081)

69 Ross IL, Bergthorsdottir R, Levitt N, Dave JA, Schatz D, Marais D \& Johannsson G. Cardiovascular risk factors in patients with Addison's disease: a comparative study of South African and Swedish patients. PLOS ONE 20149 e90768. (doi:10.1371/journal. pone.0090768)
70 Werumeus Buning J, van Faassen M, Brummelman P, Dullaart RP, van den Berg G, van der Klauw MM, Kerstens MN, Stegeman CA, Muller Kobold AC, Kema IP et al. Effects of hydrocortisone on the regulation of blood pressure: results from a randomized controlled trial. Journal of Clinical Endocrinology and Metabolism 2016101 3691-3699. (doi:10.1210/jc.2016-2216)

71 Giordano R, Marzotti S, Balbo M, Romagnoli S, Marinazzo E, Berardelli R, Migliaretti G, Benso A, Falorni A, Ghigo E et al. Metabolic and cardiovascular profile in patients with Addison's disease under conventional glucocorticoid replacement. Journal of Endocrinological Investigation 200932 917-923. (doi:10.1007/ BF03345773)

72 Johannsson G, Nilsson AG, Bergthorsdottir R, Burman P, Dahlqvist P, Ekman B, Engström BE, Olsson T, Ragnarsson O, Ryberg $\mathrm{M}$ et al. Improved cortisol exposure time profile and outcome in patients with adrenal insufficiency: a prospective randomized trial of a novel hydrocortisone dual release formulation. Journal of Clinical Endocrinology and Metabolism 2012 97 473-481. (doi:10.1210/jc.2011-1926)

73 Giordano R, Guaraldi F, Marinazzo E, Fumarola F, Rampino A, Berardelli R, Karamouzis I, Lucchiari M, Manetta T, Mengozzi $\mathrm{G}$ et al. Improvement of anthropometric and metabolic parameters, and quality of life following treatment with dualrelease hydrocortisone in patients with Addison's disease. Endocrine 201651 360-368. (doi:10.1007/s12020-015-0681-z)

74 Elbelt U, Hahner S \& Allolio B. Altered insulin requirement in patients with type 1 diabetes and primary adrenal insufficiency receiving standard glucocorticoid replacement therapy. European Journal of Endocrinology 2009160 919-924. (doi:10.1530/ EJE-08-1003)

75 Gola M, Bonadonna S, Doga M \& Giustina A. Clinical review: growth hormone and cardiovascular risk factors. Journal of Clinical Endocrinology and Metabolism 200590 1864-1870. (doi:10.1210/ jc.2004-0545)

76 Gazzaruso C, Gola M, Karamouzis I, Giubbini R \& Giustina A. Cardiovascular risk in adult patients with growth hormone $(\mathrm{GH})$ deficiency and following substitution with GH - an update. Journal of Clinical Endocrinology and Metabolism 201499 18-29. (doi:10.1210/jc.2013-2394)

77 Tomlinson JW, Holden N, Hills RK, Wheatley K, Clayton RN, Bates AS, Sheppard MC \& Stewart PM. Association between premature mortality and hypopituitarism. West Midlands Prospective Hypopituitary Study Group. Lancet 2001357 425-431. (doi:10.1016/S0140-6736(00)04006-X)

78 Stewart PM, Biller BM, Marelli C, Gunnarsson C, Ryan MP \& Johannsson G. Exploring inpatient hospitalizations and morbidity in patients with adrenal insufficiency. Journal of Clinical Endocrinology and Metabolism 2016101 4843-4850. (doi:10.1210/ jc.2016-2221)

79 Kim MS, Ryabets-Lienhard A, Dao-Tran A, Mittelman SD, Gilsanz V, Schrager SM \& Geffner ME. Increased abdominal adiposity in adolescents and young adults with classical congenital adrenal hyperplasia due to 21-hydroxylase deficiency. Journal of Clinical Endocrinology and Metabolism 2015100 1153-1159. (doi:10.1210/ jc.2014-4033)

80 Falhammar H, Frisén L, Hirschberg AL, Norrby C, Almqvist C, Nordenskjöld A \& Nordenström A. increased cardiovascular and metabolic morbidity in patients with 21-hydroxylase deficiency: a Swedish population-based national cohort study. Journal of Clinical Endocrinology and Metabolism 2015100 3520-3528. (doi:10.1210/JC.2015-2093)

81 Mazziotti GE, Canalis E \& Giustina A. Drug-induced osteoporosis: mechanisms and clinical implications. American Journal of Medicine 2010123 877-884. (doi:10.1016/j.amjmed.2010.02.028)

82 Mazziotti G, Angeli A, Bilezikian JP, Canalis E \& Giustina A. Glucocorticoid-induced osteoporosis: an update. Trends in 
Endocrinology and Metabolism 200617 144-149. (doi:10.1016/j. tem.2006.03.009)

83 Canalis E, Mazziotti G, Giustina A \& Bilezikian JP. Glucocorticoidinduced osteoporosis: pathophysiology and therapy. Osteoporosis International 200718 1319-1328. (doi:10.1007/s00198-007-0394-0)

84 Giustina A, Romanelli R, Candrina R \& Giustina G. Growth hormone deficiency in patients with idiopathic adrenocorticotropin deficiency resolves during glucocorticoid replacement. Journal of Clinical Endocrinology and Metabolism 1989 68 120-124. (doi:10.1210/jcem-68-1-120)

85 Hattori Y, Takeda T, Fujii M, Taura J, Ishii Y \& Yamada H. Dioxin-induced fetal growth retardation: the role of a preceding attenuation in the circulating level of glucocorticoid. Endocrine 201447 572-580. (doi:10.1007/s12020-014-0257-3)

86 Mazziotti G, Formenti AM, Adler RA, Bilezikian JP, Grossman A, Sbardella E, Minisola S \& Giustina A. Glucocorticoid-induced osteoporosis: pathophysiological role of GH/IGF-I and PTH/ Vitamin D axes, treatment options and guidelines. Endocrine 2016 54 603-611. (doi:10.1007/s12020-016-1146-8)

87 Giustina A, Bossoni S, Bodini C, Girelli A, Balestrieri GP, Pizzocolo $\mathrm{G} \&$ Wehrenberg WB. Arginine normalizes the growth hormone (GH) response to GH-releasing hormone in adult patients receiving chronic daily immunosuppressive glucocorticoid therapy. Journal of Clinical Endocrinology and Metabolism $1992 \mathbf{7 4}$ 1301-1305. (doi:10.1210/jc.74.6.1301)

88 Giustina A, Doga M, Bodini C, Girelli A, Legati F, Bossoni S \& Romanelli G. Acute effects of cortisone acetate on growth hormone response to growth hormone-releasing hormone in normal adult subjects. Acta Endocrinology 1990122 206-210. (doi:10.1530/acta.0.1220206)

89 Terzolo M, Bossoni S, Alí A, Doga M, Reimondo G, Milani G, Peretti P, Manelli F, Angeli A \& Giustina A. Growth hormone (GH) responses to GH-releasing hormone alone or combined with arginine in patients with adrenal incidentaloma: evidence for enhanced somatostatinergic tone. Journal of Clinical Endocrinology and Metabolism 200085 1310-1315. (doi:10.1210/jcem.85.3.6531)

90 Zelissen PM, Croughs RJ, van Rijk PP \& Raymakers JA. Effect of glucocorticoid replacement therapy on bone mineral density in patients with Addison disease. Annals of Internal Medicine 1994 120 207-210. (doi:10.7326/0003-4819-120-3-199402010-00005)

91 Jódar E, Valdepeñas MP, Martinez G, Jara A \& Hawkins F. Longterm follow-up of bone mineral density in Addison's disease. Clinical Endocrinology 200358 617-620. (doi:10.1046/j.13652265.2003.01761.x)

92 Løvås K, Gjesdal CG, Christensen M, Wolff AB, Almås B, Svartberg J, Fougner KJ, Syversen U, Bollerslev J, Falch JA et al. Glucocorticoid replacement therapy and pharmacogenetics in Addison's disease: effects on bone. European Journal of Endocrinology 2009160 993-1002. (doi:10.1530/eje-08-0880)

93 Mazziotti G, Porcelli T, Bianchi A, Cimino V, Patelli I, Mejia C, Fusco A, Giampietro A, De Marinis L \& Giustina A. Glucocorticoid replacement therapy and vertebral fractures in hypopituitary adult males with GH deficiency. European Journal of Endocrinology 2010163 15-20. (doi:10.1530/EJE-10-0125)

94 Koetz KR, Ventz M, Diederich S \& Quinkler M. Bone mineral density is not significantly reduced in adult patients on lowdose glucocorticoid replacement therapy. Journal of Clinical Endocrinology and Metabolism 201297 85-92. (doi:10.1210/ jc.2011-2036)

95 Falhammar H, Filipsson Nyström H, Wedell A, Brismar K \& Thorén M. Bone mineral density, bone markers, and fractures in adult males with congenital adrenal hyperplasia. European Journal of Endocrinology 2013168 331-341. (doi:10.1530/EJE-12-0865)

96 Ceccato F, Barbot M, Albiger N, Zilio M, De Toni P, Luisetto G, Zaninotto M, Greggio NA, Boscaro M, Scaroni C et al. Long-term glucocorticoid effect on bone mineral density in patients with congenital adrenal hyperplasia due to 21-hydroxylase deficiency. European Journal of Endocrinology 2016175 101-106. (doi:10.1530/ EJE-16-0104)

97 Peacey SR, Yuan Guo C, Eastell R \& Weetman AP. Optimization of glucocorticoid replacement therapy: the long-term effect on bone mineral density. Clinical Endocrinology 199950 815-817. (doi:10.1046/j.1365-2265.1999.00787.x)

98 Schulz J, Frey KR, Cooper MS, Zopf K, Ventz M, Diederich S \& Quinkler M. Reduction in daily hydrocortisone dose improves bone health in primary adrenal insufficiency. European Journal of Endocrinology 2016174 531-538. (doi:10.1530/EJE-15-1096)

99 Mazziotti G, Chiavistelli S \& Giustina A. Pituitary diseases and bone. Endocrinology and Metabolism of Clinics of North America 201544 171-180. (doi:10.1016/j.ecl.2014.10.014)

100 Mazziotti G, Dordoni C, Doga M, Galderisi F, Venturini M, Calzavara-Pinton P, Maroldi R, Giustina A \& Colombi M. High prevalence of radiological vertebral fractures in adult patients with Ehlers-Danlos syndrome. Bone 201684 88-92. (doi:10.1016/j. bone.2015.12.007)

101 Pedersini R, Monteverdi S, Mazziotti G, Amoroso V, Roca E, Maffezzoni F, Vassalli L, Rodella F, Formenti AM, Frara S et al. Morphometric vertebral fractures in breast cancer patients treated with adjuvant aromatase inhibitor therapy: a cross-sectional study. Bone 201797 147-152. (doi:10.1016/j.bone.2017.01.013)

102 Björnsdottir S Sääf M, Bensing S, Kämpe O, Michaëlsson K \& Ludvigsson JF. Risk of hip fracture in Addison's disease: a population-based cohort study. Journal of Internal Medicine 2011 270 187-195. (doi:10.1111/j.1365-2796.2011.02352.x)

103 Mazziotti G, Doga M, Frara S, Maffezzoni F, Porcelli T, Cerri L, Maroldi R \& Giustina A. Incidence of morphometric vertebral fractures in adult patients with growth hormone deficiency. Endocrine 201652 103-110. (doi:10.1007/s12020-015-0738-z)

104 Falhammar H, Filipsson H, Holmdahl G, Janson PO, Nordenskjöld A, Hagenfeldt K \& Thorén M. Fractures and bone mineral density in adult women with 21-hydroxylase deficiency. Journal of Clinical Endocrinology and Metabolism 200792 4643-4649. (doi:10.1210/ jc.2007-0744)

$105 \varnothing$ Øssnes M, Bensing S, Hulting AL, Kämpe O, Hackemann A, Meyer G, Badenhoop K, Betterle C, Parolo A, Giordano R et al. Quality of life in European patients with Addison's disease: validity of the disease-specific questionnaire AddiQoL. Journal of Clinical Endocrinology and Metabolism 201297 568-576. (doi:10.1210/ jc.2011-1901)

106 Kluger N, Matikainen N, Sintonen H, Ranki A, Roine RP \& Schalin-Jäntti C. Impaired health-related quality of life in Addison's disease - impact of replacement therapy, comorbidities and socio-economic factors. Clinical Endocrinology 201481 511-518. (doi:10.1111/cen.12484)

107 Meyer G, Hackemann A, Penna-Martinez M \& Badenhoop K. What affects the quality of life in autoimmune Addison's disease? Hormone and Metabolic Research 201345 92-95. (doi:10.105 5/s-0032-1331766)

108 Løvås K, Loge JH \& Husebye ES. Subjective health status in Norwegian patients with Addison's disease. Clinical Endocrinology 200256 581-588. (doi:10.1046/j.1365-2265.2002.01466.x)

109 Arlt W, Willis DS, Wild SH, Krone N, Doherty EJ, Hahner S, Han TS, Carroll PV, Conway GS, Rees DA et al. Health status of adults with congenital adrenal hyperplasia: a cohort study of 203 patients. Journal of Clinical Endocrinology and Metabolism 201095 5110-5121. (doi:10.1210/jc.2010-0917)

110 Thomsen AF, Kvist TK, Andersen PK \& Kessing LV. The risk of affective disorders in patients with adrenocortical insufficiency. Psychoneuroendocrinology 200631 614-622. (doi:10.1016/j. psyneuen.2006.01.003)

111 Hahner S, Loeffler M, Fassnacht M, Weismann D, Koschker AC Quinkler M, Decker O, Arlt W \& Allolio B. Impaired subjective 
health status in 256 patients with adrenal insufficiency on standard therapy based on cross-sectional analysis. Journal of Clinical Endocrinology and Metabolism 200792 3912-3922. (doi:10.1210/jc.2007-0685)

112 Bleicken B, Hahner S, Ventz M \& Quinkler M. Delayed diagnosis of adrenal insufficiency is common: a cross-sectional study in 216 patients. American Journal of Medical Science 2010339 525-531. (doi:10.1097/MAJ.0b013e3181db6b7a)

113 Erichsen MM, Løvås K, Skinningsrud B, Wolff AB, Undlien DE, Svartberg J, Fougner KJ, Berg TJ, Bollerslev J, Mella B et al. Clinical, immunological, and genetic features of autoimmune primary adrenal insufficiency: observations from a Norwegian registry. Journal of Clinical Endocrinology and Metabolism 200994 48824890. (doi:10.1210/jc.2009-1368)

114 Løvås K, Husebye ES, Holsten F \& Bjorvatn B. Sleep disturbances in patients with Addison's disease. European Journal of Endocrinology 2003148 449-456. (doi:10.1530/eje.0.1480449)

115 Henry M, Wolf PS, Ross IL \& Thomas KG. Poor quality of life, depressed mood, and memory impairment may be mediated by sleep disruption in patients with Addison's disease. Physiology Behaviour 2015151 379-385. (doi:10.1016/j. physbeh.2015.08.011)

116 Crespo I, Valassi E, Santos A \& Webb SM. Health-related quality of life in pituitary diseases. Endocrinology and Metabolism of Clinics of North America 201544 161-170. (doi:10.1016/j.ecl.2014.10.013)

117 Reisch N, Hahner S, Bleicken B, Flade L, Pedrosa Gil F, Loeffler M, Ventz M, Hinz A, Beuschlein F, Allolio B et al. Quality of life is less impaired in adults with congenital adrenal hyperplasia because of 21-hydroxylase deficiency than in patients with primary adrenal insufficiency. Clinical Endocrinology 201174 166-173. (doi:10.1111/j.1365-2265.2010.03920.x)

118 Falhammar H \& Nordenström A. Nonclassic congenital adrenal hyperplasia due to 21-hydroxylase deficiency: clinical presentation, diagnosis, treatment, and outcome. Endocrine 2015 50 32-50. (doi:10.1007/s12020-015-0656-0)

119 Falhammar H, Nyström HF \& Thorén M. Quality of life, social situation, and sexual satisfaction, in adult males with congenital adrenal hyperplasia. Endocrine 201447 299-307. (doi:10.1007/ s12020-013-0161-2)

120 Han TS, Krone N, Willis DS, Conway GS, Hahner S, Rees DA, Stimson RH, Walker BR, Arlt W \& Ross RJ. Quality of life in adults with congenital adrenal hyperplasia relates to glucocorticoid treatment, adiposity and insulin resistance: United Kingdom congenital adrenal Hyperplasia Adult Study Executive (CaHASE). European Journal of Endocrinology 2013168 887-893. (doi:10.1530/ EJE-13-0128)

121 Wichers M, Springer W, Bidlingmaier F \& Klingmüller D. The influence of hydrocortisone substitution on the quality of life and parameters of bone metabolism in patients with secondary hypocortisolism. Clinical Endocrinology 199950 759-765. (doi:10.1046/j.1365-2265.1999.00723.x)

122 Alonso N, Granada ML, Lucas A, Salinas I, Reverter J, Oriol A \& Sanmarti A. Evaluation of two replacement regimens in primary adrenal insufficiency patients. Effect on clinical symptoms, health-related quality of life and biochemical parameters. Journal of Endocrinological Investigation 200427 449-454. (doi:10.1007/ BF03345290)

123 Behan LA, Rogers B, Hannon MJ, O'Kelly P, Tormey W, Smith D, Thompson CJ \& Agha A. Optimizing glucocorticoid replacement therapy in severely adrenocorticotropin-deficient hypopituitary male patients. Clinical Endocrinology 201175 505-513. (doi:10.1111/j.1365-2265.2011.04074.x)

124 Benson S, Neumann P, Unger N, Schedlowski M, Mann K, Elsenbruch S \& Petersenn S. Effects of standard glucocorticoid replacement therapies on subjective well-being: a randomized, double-blind, crossover study in patients with secondary adrenal insufficiency. European Journal of Endocrinology 2012167 679-685. (doi:10.1530/EJE-12-0351)

125 Ekman B, Bachrach-Lindström M, Lindström T, Wahlberg J, Blomgren J \& Arnqvist HJ. A randomized, double-blind, crossover study comparing two- and four-dose hydrocortisone regimen with regard to quality of life, cortisol and ACTH profiles in patients with primary adrenal insufficiency. Clinical Endocrinology 201277 18-25. (doi:10.1111/j.1365-2265.2012.04352.x)

126 Werumeus Buning J, Brummelman P, Koerts J, Dullaart RP, van den Berg G, van der Klauw MM, Sluiter WJ, Tucha O, Wolffenbuttel BH \& van Beek AP. Hydrocortisone dose influences pain, depressive symptoms and perceived health in adrenal insufficiency: a randomized controlled trial. Neuroendocrinology 2016103 771-778. (doi:10.1159/000442985)

127 Bleicken B, Hahner S, Loeffler M, Ventz M, Allolio B \& Quinkler $\mathrm{M}$. Impaired subjective health status in chronic adrenal insufficiency: impact of different glucocorticoid replacement regimens. European Journal of Endocrinology 2008159 811-817. (doi:10.1530/EJE-08-0578)

128 Bleicken B, Hahner S, Loeffler M, Ventz M, Decker O, Allolio B \& Quinkler M. Influence of hydrocortisone dosage scheme on health-related quality of life in patients with adrenal insufficiency. Clinical Endocrinology 201072 297-304. (doi:10.1111/j.13652265.2009.03596.x)

129 Tiemensma J, Andela CD, Kaptein AA, Romijn JA, van der Mast RC, Biermasz NR \& Pereira AM. Psychological morbidity and impaired quality of life in patients with stable treatment for primary adrenal insufficiency: cross-sectional study and review of the literature. European Journal of Endocrinology 2014171 171-182. (doi:10.1530/EJE-14-0023)

130 Ragnarsson O, Mattsson AF, Monson JP, Filipsson Nyström $\mathrm{H}_{\text {, }}$ Åkerblad AC, Kołtowska-Häggström M \& Johannsson G. The relationship between glucocorticoid replacement and quality of life in 2737 hypopituitary patients. European Journal of Endocrinology 2014171 571-579. (doi:10.1530/EJE-14-0397)

131 Bergthorsdottir R, Leonsson-Zachrisson M, Odén A \& Johannsson G. Premature mortality in patients with Addison's disease: a population-based study. Journal of Clinical Endocrinology and Metabolism 200691 4849-4853. (doi:10.1210/jc.2006-0076)

132 Bensing S, Brandt L, Tabaroj F, Sjöberg O, Nilsson B, Ekbom A, Blomqvist P \& Kämpe O. Increased death risk and altered cancer incidence pattern in patients with isolated or combined autoimmune primary adrenocortical insufficiency. Clinical Endocrinology 200869 697-704. (doi:10.1111/j.13652265.2008.03340.x)

133 Erichsen MM, Løvås K, Fougner KJ, Svartberg J, Hauge ER, Bollerslev J, Berg JP, Mella B \& Husebye ES. Normal overall mortality rate in Addison's disease, but young patients are at risk of premature death. European Journal of Endocrinology 2009160 233-237. (doi:10.1530/EJE-08-0550)

134 Rosen T \& Bengtsson BA. Premature mortality due to cardiovascular disease in hypopituitarism. Lancet 1990336 285-288. (doi:10.1016/0140-6736(90)91812-O)

135 Giustina A, Barkan A, Chanson P, Grossman A, Hoffman A, Ghigo E, Casanueva F, Colao A, Lamberts S, Sheppard M et al. Guidelines for the treatment of growth hormone excess and growth hormone deficiency in adults. Journal of Endocrinological Investigation 2008 31 820-838. (doi:10.1007/BF03349263)

136 Gaillard RC, Mattsson AF, Akerblad AC, Bengtsson BÅ, Cara J, Feldt-Rasmussen U, Koltowska-Häggström M, Monson JP, Saller B, Wilton P et al. Overall and cause-specific mortality in GH-deficient adults on GH replacement. European Journal of Endocrinology 2012 166 1069-1077. (doi:10.1530/EJE-11-1028)

137 Burman P, Mattsson AF, Johannsson G, Höybye C, Holmer H, Dahlqvist P, Berinder K, Engström BE, Ekman B, Erfurth EM et al. Deaths among adult patients with hypopituitarism: 
hypocortisolism during acute stress, and de novo malignant brain tumors contribute to an increased mortality. Journal of Clinical Endocrinology and Metabolism 201398 1466-1475. (doi:10.1210/ jc.2012-4059)

138 Hahner S, Spinnler C, Fassnacht M, Burger-Stritt S, Lang K, Milovanovic D, Beuschlein F, Willenberg HS, Quinkler M \& Allolio B. High incidence of adrenal crisis in educated patients with chronic adrenal insufficiency: a prospective study. Journal of Clinical Endocrinology and Metabolism 2015100 407-416. (doi:10.1210/jc.2014-3191)

139 Mills JL, Schonberger LB, Wysowski DK, Brown P, Durako SJ, Cox C, Kong F \& Fradkin JE. Long-term mortality in the United States cohort of pituitary-derived growth hormone recipients. Journal of Pediatrics 2004144 430-436. (doi:10.1016/j.jpeds.2003.12.036)

140 Falhammar H, Frisén L, Norrby C, Hirschberg AL, Almqvist C, Nordenskjöld A \& Nordenström A. Increased mortality in patients with congenital adrenal hyperplasia due to 21-hydroxylase deficiency. Journal of Clinical Endocrinology and Metabolism 201299 E2715-E2721. (doi:10.1210/jc.2014-2957)

141 Sideris S, Aoun F, Martinez CN, Latifyan S, Awada A, Costante G $\&$ Gil T. Role of corticosteroids in prostate cancer progression: implications for treatment strategy in metastatic castrationresistant patients. Journal of Endocrinological Investigation 201639 729-738. (doi:10.1007/s40618-016-0430-z)

142 Debono M, Ross RJ \& Newell-Price J. Inadequacies of glucocorticoid replacement and improvements by physiological circadian therapy. European Journal of Endocrinology 2009160 719-729. (doi:10.1530/EJE-08-0874)

143 Johannsson G. Improving glucocorticoid replacement in patients with adrenal insufficiency. Endocrine 201652 405-407. (doi:10.1007/s12020-016-0929-2)

144 Jones CM, Mallappa A, Reisch N, Nikolaou N, Krone N, Hughes BA, O'Neil DM, Whitaker MJ, Tomlinson JW, Storbeck KH et al. Modified release and conventional glucocorticoids and diurnal androgen excretion in congenital adrenal hyperplasia. Journal of Clinical Endocrinology and Metabolism 2017102 1797-1806. (doi:10.1210/jc.2016-2855)

145 Nella AA, Mallappa A, Perritt AF, Gounden V, Kumar P, Sinaii N, Daley LA, Ling A, Liu CY, Soldin SJ et al. A Phase 2 study of continuous subcutaneous hydrocortisone infusion in adults with congenital adrenal hyperplasia. Journal of Clinical Endocrinology and Metabolism 2016101 4690-4698. (doi:10.1210/jc.2016-1916)

146 Nilsson AG, Marelli C, Fitts D, Bergthorsdottir R, Burman P, Dahlqvist P, Ekman B, Engström BE, Olsson T, Ragnarsson $\mathrm{O}$ et al. Prospective evaluation of long-term safety of dual-release hydrocortisone replacement administered once daily in patients with adrenal insufficiency. European Journal of Endocrinology 2014 171 369-377. (doi:10.1530/EJE-14-0327)

147 Quinkler M, Miodini Nilsen R, Zopf K, Ventz M \& Øksnes M. Modified-release hydrocortisone decreases BMI and HbA1c in patients with primary and secondary adrenal insufficiency. European Journal of Endocrinology 2015172 619-626. (doi:10.1530/ EJE-14-1114)

148 Hummel SR, Sadler S, Whitaker MJ, Ara RM, Dixon S \& Ross RJ. A model for measuring the health burden of classic congenital adrenal hyperplasia in adults. Clinical Endocrinology 201685 361-398. (doi:10.1111/cen.13060)

149 Pia A, Vignani F, Attard G, Tucci M, Bironzo P, Scagliotti G, Arlt W, Terzolo M \& Berruti A. Strategies for managing ACTH dependent mineralocorticoid excess induced by abiraterone. Cancer Treatment Reviews 201339 966-973. (doi:10.1016/j. ctrv.2013.03.003)

150 Richards J, Lim AC, Hay CW, Taylor AE, Wingate A, Nowakowska K, Pezaro C, Carreira S, Goodall J, Arlt W et al. Interactions of abiraterone, eplerenone, and prednisolone with wild-type and mutant androgen receptor: a rationale for increasing abiraterone exposure or combining with MDV3100. Cancer Research 201272 2176-2182. (doi:10.1158/0008-5472. CAN-11-3980)

151 Orena S, Maurer TS, She L, Eudy R, Bernardo V, Dash D, Loria P, Banker ME, Tugnait M, Okerberg CV et al. PF-03882845, a nonsteroidal mineralocorticoid receptor antagonist, prevents renal injury with reduced risk of hyperkalemia in an animal model of nephropathy. Frontiers in Pharmacology 201314115.

152 Valcamonico F, Bedussi F, Galli D, Dallavolta A, Fragni M, Vezzoli S, Farrari VD, Lazzari B, Ferrari L, De Ferrari F et al. Amiloride effects on abiraterone antiproliferative activity in prostate cancer cells in vitro and on clinical management of abiraterone induced mineralocorticoid excess syndrome. Journal of Clinical Oncology 201634 (2 Supplement 5) 175 (meeting abstract). (doi:10.1200/ jco.2016.34.2_suppl.175)

153 Berruti A, Baudin E, Gelderblom H, Haak HR, Porpiglia F, Fassnacht M, Pentheroudakis G \& ESMO Guidelines Working Group. Adrenal cancer: ESMO Clinical Practice Guidelines for diagnosis, treatment and follow-up. Annals of Oncology 201223 (Supplement 7) vii131-vii138. (doi:10.1093/annonc/mds231)

154 Weigel M, Hahner S, Sherlock M, Agha A, Behan LA, Stewart PM, Arlt W, Beier D, Frey K, Zopf K et al. Immediate versus modified release hydrocortisone in mitotane treated patients with adrenocortical cancer. Clinical Endocrinology 201786 499-505. (doi:10.1111/cen.13302)

Received 22 February 2017

Revised version received 31 May 2017

Accepted 5 June 2017 